Yurij K.Vasil'chuk ${ }^{*}$, Alla C.Vasil'chuk ${ }^{2}$, Högne Jungner ${ }^{3}$,

Nadine A. Budantseva ${ }^{4}$, Julia N. Chizhova 5

${ }^{1}$ Department of Landscape Geochemistry and Soil Geography, Lomonosov Moscow State University, e-mail vasilch@geol.msu.ru \& vasilch_geo@mail.ru

*Corresponding author

2 Laboratory of Geoecology of the North, Lomonosov Moscow State University, e-mail alla-vasilch@yandex.ru

3 Helsinki University, Helsinki, Finland, e-mail hogne.jungner@helsinki.fi

${ }^{4}$ Department of Landscape Geochemistry and Soil Geography, Lomonosov Moscow State University, e-mail nadin.budanceva@mail.ru

${ }^{5}$ Department of Landscape Geochemistry and Soil Geography, Lomonosov Moscow State University, e-mail eacentr@yandex.ru

\title{
RADIOCARBON CHRONOLOGY OF HOLOCENE PALSA \\ OF BOL'SHEZEMEL'SKAYA TUNDRA IN RUSSIAN NORTH
}

ABSTRACT. Six palsa mire in Usa River valley and in Vorkuta area in North-eastern part of European Russia were studied in detail. In total 75 new ${ }^{14} \mathrm{C}$ dates from different palsa sections were obtained. In palsa mire near Bugry Settlement 3.2 m high palsa dated from 8.6 to $2.1 \mathrm{ka} \mathrm{BP}$. The permafrost and palsa began $2.1 \mathrm{ka}$ BP. In palsa mire near Usa Settlement low moor peat in $2 \mathrm{~m}$ high palsa dated 3690 BP, palsa began to heave at least 3700 BP. A low-moor peat of $2.5 \mathrm{~m}$ high palsa indicates the change in the hydrologicalmineral regime during 7.1 to $6.3 \mathrm{ka} \mathrm{BP}$, heaving commenced 6 ka BP. A number of $8{ }^{14} \mathrm{C}$ dates from 5.6 to $2.7 \mathrm{ka} \mathrm{BP}$ obtained from peat of $3 \mathrm{~m}$ high palsa. Near Abez' Settlement palsa development began about $2.8 \mathrm{ka}$ BP. There are both large and smaller palsas. Low-moor peat of $3.5 \mathrm{~m}$ high palsa is dated between 9180 BP to 6730 BP near Nikita Settlement. In Vorkuta area near Khanovey Settlement the northern most palsa is found. The ${ }^{14} \mathrm{C}$ age of peat at slope of the palsa is much younger, than in an axial part, there is inversion of the dates: the date $3.5 \mathrm{ka}$ $\mathrm{BP}$ is between dates 2.9 and $2.8 \mathrm{ka} \mathrm{BP}$. It is probably caused by creep of peat downwards from a summit. This evidenced this frozen mound is real palsa, but not a residual form as a result of erosion.

KEY WORDS: palsa; permafrost; mires; NorthEastern Europe; radiocarbon.

\section{INTRODUCTION}

Palsas represent one of the most widespread forms of permafrost terrain. They are abundant in areas of discontinuous permafrost with mean annual temperatures close to the freezing point, although they are also sufficiently common in the zone of low-temperature continuous permafrost [Ǻhman, 1976; Seppälä, 1986; Pissart, 1983; Washburn, 1983; Vasil'chuk, 1983; Vasil'chuk, Vasil'chuk, 1998; Allard, Rousseau, 1999; Westin, Zuidhoff, 2001; Cyr, Payette, 2010; Seppälä, 2011; Christensen et al., 2012; Magnan et al., 2012; Farbrot et al., 2013]. It is normally assumed that palsas are relatively old (older than 4-5 ka BP), and are today generally subjected to degradation [Popov, 1967; Yevseev, 1976]. The aim of this paper is to determine the time of formation of palsa in different geocryologic environments in North-Eastern European 


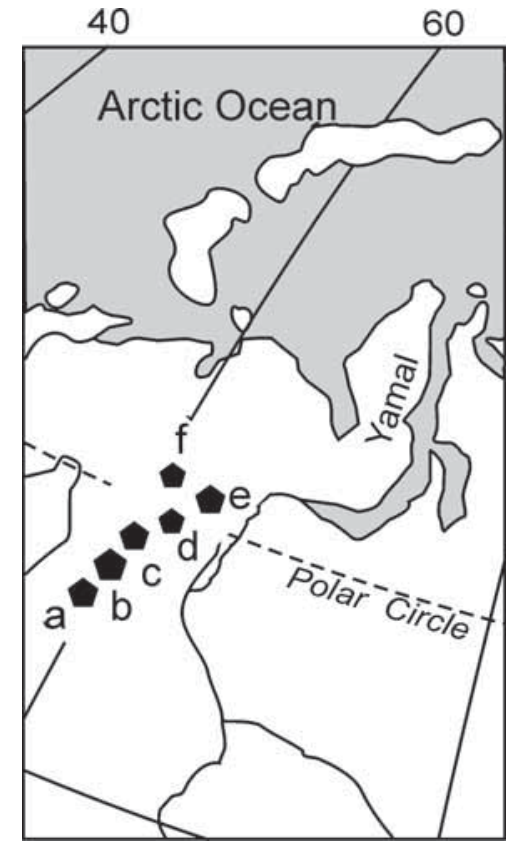

Fig. 1. Map of palsa localities mentioned in text:

Usa River valley: near Bugry (a), Usa (b),

Abez' (c) Nikita (d), Eletskaya (e) Khanovey (f) settlements

part of Russia, north Usa River valley and in Vorkuta area (Fig. 1).

In these areas palsas of different configuration, height and age are widespread. Detailed dating of the peat covering the frost mound and plant macrofossil analysis allow to determine the initial stage of palsa growth and to separate the palsa peat on its lowmoor (eutrophic) and high-moor-transitional (oligotrophic-mesotrophic) types. Hummocky peat bogs represent one of the most appropriate objects for radiocarbon dating. Autochthonous organic material is usually prevalent in such peat. There are virtually no age inversions in the radiocarbon dates obtained from the examined palsa shown in cross-sections excepting special case of Khanovey palsa.

\section{METHODS}

Taking into account that commonly palsa growth begin after accumulation of peat cover, we have concentrated the attention on detailed radiocarbon dating and detailed botanical and palynological study of the peat overlapping palsa. The whole palsa history such as its growth, stabilization and degradation, is recorded in the peat.

The radiocarbon dates were obtained in the Radiocarbon Laboratory of the Geological Institute (GIN) of the Russian Academy of Sciences and the Radiocarbon Laboratory at the University of Helsinki (Hel). Both dating laboratories have long experience in dating peat samples and are well aware of the problems involved.

In Dating Laboratory of Geological Institute RAS the alkaline extract from the peat was dated. ${ }^{14} \mathrm{C}$ is measured by the liquid scintillation counting technique using 8 twochannel beta-counting spectrophotometers. The benzene-production process, worked out by L.Sulezhitsky, differs from the more conventional method in that lithium carbide is produced by reacting the pretreated samples directly with lithium, rather than combusting the samples to $\mathrm{CO}_{2}$ and reacting the $\mathrm{CO}_{2}$ with lithium.

In the Helsinki Laboratory rootlets were first removed and the samples treated by a standard acid-alkali-acid. The fulvic and humus fractions are thus removed and the innermost part of the peat is dated.

For all samples measured in Helsinki $\delta^{13} \mathrm{C}$ values were measured and the dates corrected accordingly. For the peat samples the mean $\delta^{13} \mathrm{C}$ value is $-29.0 \%$ and the standard deviation $0.7 \%$. If this value can be applied also to the results from the Moscow laboratory the age correction for them would be about 30 years. The samples from the most representative cross-sections of palsa were dated in both laboratories simultaneously and independently. The scheme of dating was as follow: dates from one laboratory were located between the dates from the other laboratory. This provided high precision of the ${ }^{14} \mathrm{C}$ dates obtained and a test on the different methods used in the two laboratories. 
RESULTS

Six palsa mires were studied in detail in Usa River valley and in Vorkuta area in Northeastern part of European Russia. In total 75 radiocarbon dates from different palsa sections were obtained (Table 1).

Palsa mires near Bugry Station. The southernmost large palsa mire $(300 \times 500 \mathrm{~m})$ is located near Bugry Station $\left(66^{\circ} 23^{\prime} \mathrm{N}, 61^{\circ} 24^{\prime} \mathrm{E}\right), 27 \mathrm{~km}$ $\mathrm{S}$ of the Abez'Settlement and $72 \mathrm{~km} \mathrm{~N}$ of Inta town at the $2070 \mathrm{~km}$ point of the railway line Moscow - Vorkuta. About 15 dome shaped palsas are found at the mire. The dimensions of the palsas range from $15 \times 30$ to $40 \times 80 \mathrm{~m}$, their height is $3 \mathrm{~m}$ or more (Fig. 2, a).

The cross-section of a $3.2 \mathrm{~m}$ high palsa was investigated (Fig. 3, a). The palsa has begun to destroy, two large present day deflation depressions are located on its periphery. Dwarf birch of $1 \mathrm{~m}$ height grow on its slopes, and Spagnum and Ledum palustre cover the central part. There are some grasses and sedges in inter mound depressions.

The sediment sequence is as follows from the top to the bottom of the palsa pit (Fig. 3, a):

0.0-0.05 m - Lichens cover

0.05-0.17 m - Brown, dense peat

0.17-0.35 m - Peat with leaves

$0.35-0.45 \mathrm{~m}$ - Peat

$0.45-0.5 m$ - Frozen peat from the bottom of active layer
0.5-0.7 m - Frozen peat with loam and bark, with ice lenses.

Seven samples from the central part of the palsa were ${ }^{14} \mathrm{C}$ dated (Table 1). The results show that peat began to accumulate about 8.6 ka BP. Peat accumulation was continuous about $6.5 \mathrm{ka}$ in non permafrost conditions because the peat consists of low moor, well decomposed wooden-sedge peat. Freezing and palsa growth began about 2.3-2.1 ka BP, the evidence is appearance of $d$ warf birch and Sphagnum mosses in the peat. Subsequently peat accumulation ceased at this palsa.

Palsa mire near Usa Settlement. In the lakebog area in the vicinity of the Usa Settlement $\left(66^{\circ} 31^{\prime} \mathrm{N}, 61^{\circ} 40^{\prime} \mathrm{E}\right.$ ) both high (up to $4 \mathrm{~m}$ high Fig. 4, a) and small (less than $1 \mathrm{~m}$ - Fig. 4, b) palsas can be found. The larch-birch open woodland is located in the periphery of this area. Only in the central part of the lake-bog depression there are two palsas more then $1 \mathrm{~m}$ high. Two birches were growing at the slope of one of the palsas. In the $0.4 \mathrm{~m}$ thick peat section (Fig. 5, a) overlying a relatively young, $0.8 \mathrm{~m}$ high palsa the grass-hypnum low-moor peat occurring at a depth of 0.35 $0.4 \mathrm{~m}$ can be referred to a subaqueous stage. This peat is dated to $2090 \pm 40$ BP (Table 2). The heaving process initiated probably at the time when accumulation of this basal peat layer already occurred. A second palsa studied is about $2 \mathrm{~m}$ high and $5 \times 13 \mathrm{~m}$ in size (Fig. $5, a$ ). Its peat section encloses a layer of grass low-moor peat with a fine-

Table 1. Radiocarbon dates of peat in palsa near Bugry Station, North-eastern part of European Russia, Usa River valley

\begin{tabular}{|c|c|c|c|c|c|}
\hline $\begin{array}{c}\text { Radiocarbon } \\
\text { dates (BP) }\end{array}$ & $\begin{array}{l}\text { Laboratory } \\
\text { number }\end{array}$ & $\begin{array}{c}\text { Field } \\
\text { number }\end{array}$ & $\begin{array}{l}\text { Depth, } \\
\text { m }\end{array}$ & Material & $\begin{array}{c}\text { Decom- } \\
\text { position } \\
\text { degree, \% }\end{array}$ \\
\hline $2150 \pm 30$ & GIN-11968 & $386-Y u V / 1$ & $0.05-0.17$ & Peat dense brown, grass-wood & 65 \\
\hline $2310 \pm 30$ & GIN-11969 & $386-Y u V / 2$ & $0.2-0.3$ & Peat with leaves, wood (birch) & 55 \\
\hline $3460 \pm 30$ & $\mathrm{GIN}-11970$ & $386-Y u V / 3$ & $0.3-0.35$ & Peat hypnum, low moor & $60-65$ \\
\hline $4240 \pm 30$ & GIN-11971 & $386-Y u V / 4$ & $0.35-0.45$ & Peat, sedge-wood low moor & 60 \\
\hline $5040 \pm 30$ & GIN-11972 & $386-Y u V / 5$ & $0.45-0.5$ & Peat sedge-wood & 50 \\
\hline $6250 \pm 30$ & GIN-11973 & $386-Y u V / 6$ & $0.6-0.7$ & Peat frozen, grass-wood with loam and bark & 55 \\
\hline $8690 \pm 50$ & GIN-11974 & 386-YuV/7 & $0.7-0.8$ & Peat, grass low moor & 45 \\
\hline
\end{tabular}



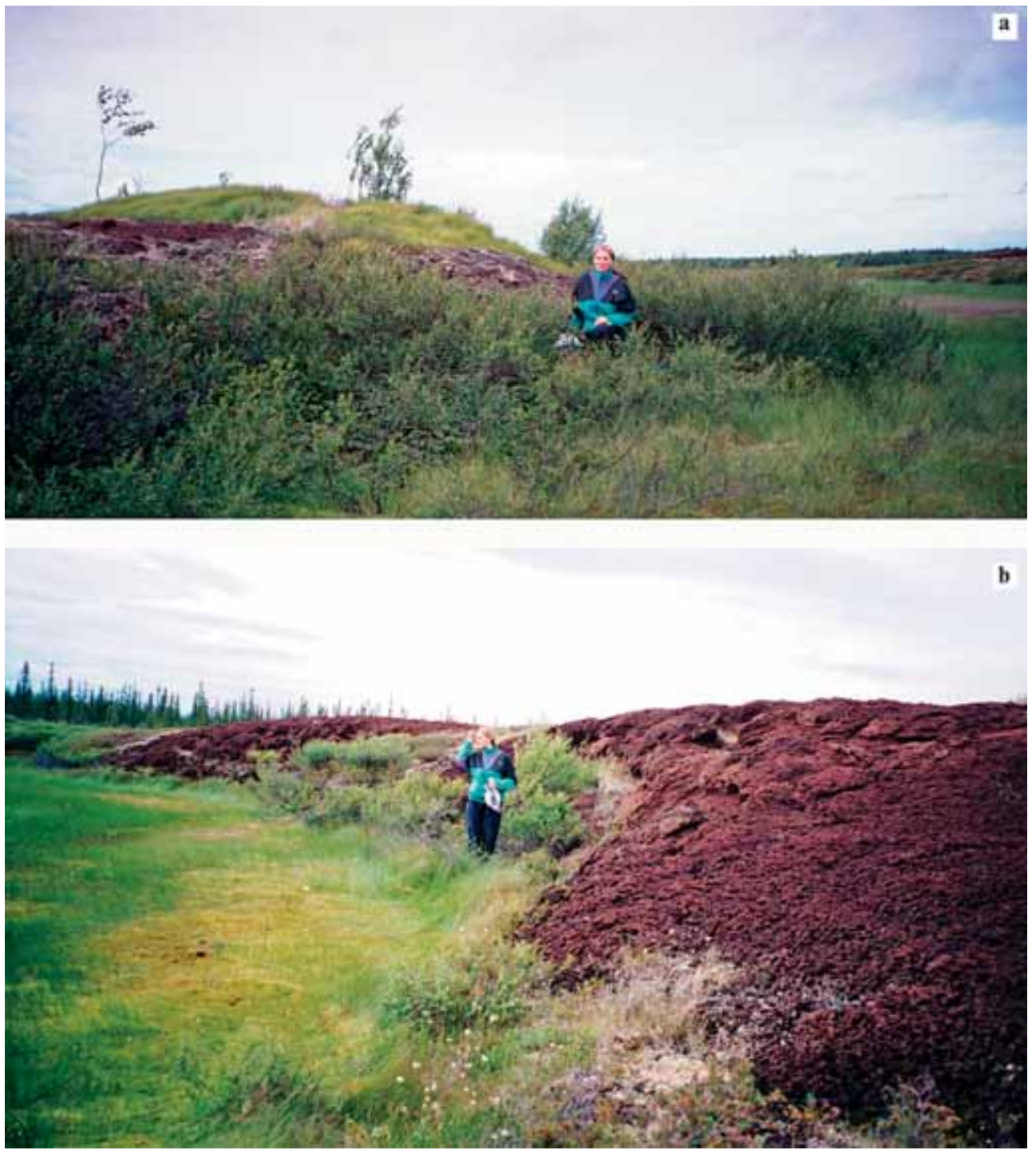

Fig. 2. Palsa mire near (A) Bugry and (B) Abez' settlements, Usa River valley

grained sand admixture located at a depth of $0.4 \mathrm{~m}$. The peat includes remains of birch (bark of Betula, 5\%), cotton grass (Eriophorum), horsetail (Equisetum, 10\%), sedge (Carex rostrata, 1\%), buckbean (Menyanthes trifoliata, 50\%), grasses and hypnaceous mosses. This peat layer is dated to $3690 \pm$ $\pm 50 \mathrm{BP}$, which corresponds most likely to the subaqueous stage. Consequently the palsa began to heave around $3700 \mathrm{BP}$.

The third palsa studied in this area is $2.5 \mathrm{~m}$ high and $8 \times 8 \mathrm{~m}$ in size (Fig. $5, a$ ). The palsa section demonstrates upward replacement of a sedge peat composed of Menyanthes trifoliata, Carex chordarrhiza, C. caespitosa, and hypnaceous moss Polytrichum strictum by a peat largely consisting of buckbean (Menyanthes trifoliata) accompanied by Carex chordarrhiza and Equisetum.

Although both these peat layers are referred to as low-moor type, the replacement of sedge peat by buckbean peat indicates initiation of the change in the hydrological-mineral regime during the time interval 7.1 to $6.3 \mathrm{ka} \mathrm{BP}$ 


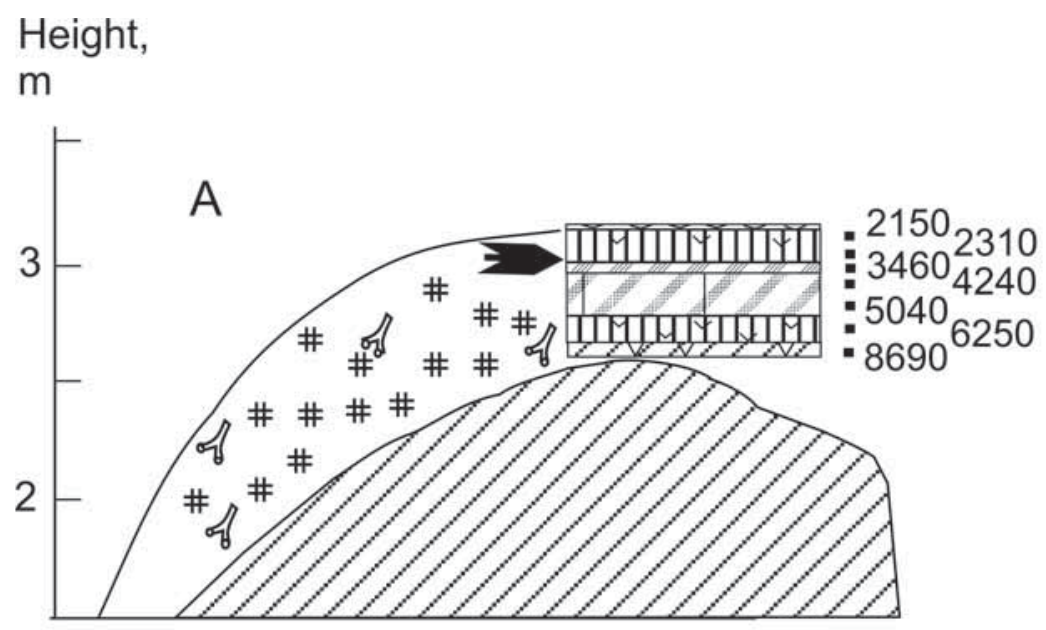

Height,

$\mathrm{m}$
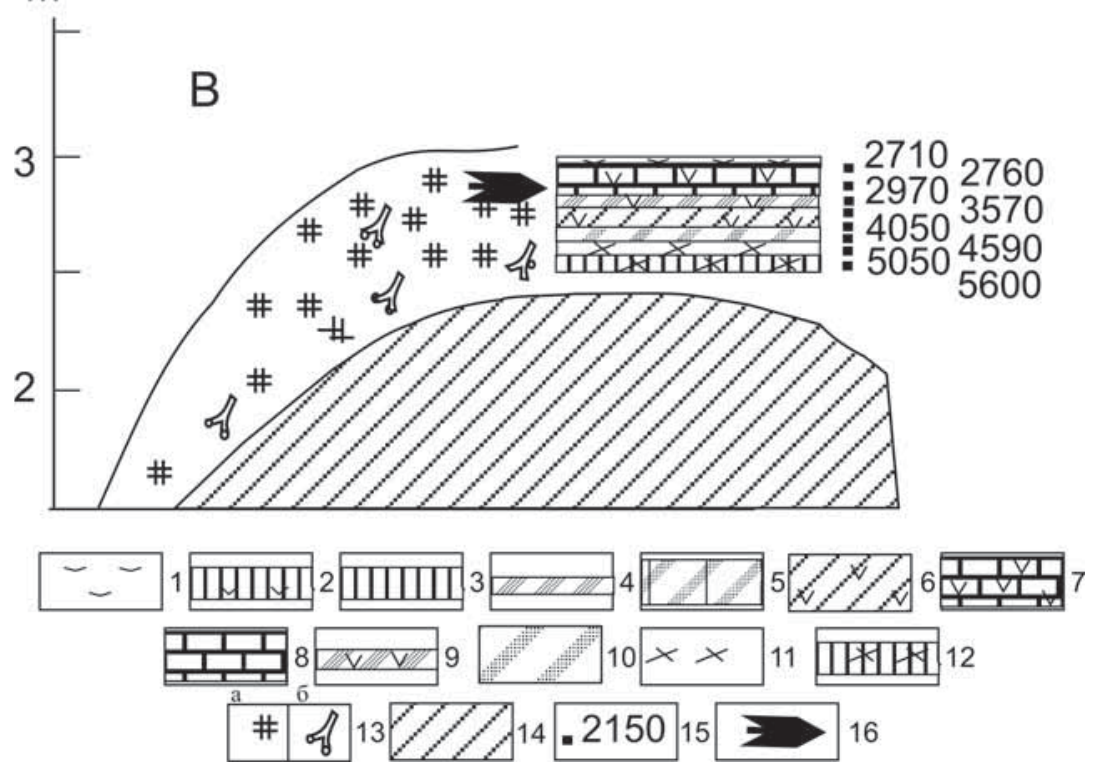

Fig. 3. Radiocarbon dated palsas near (A) Bugry and (B) Abez' settlements, in Usa River valley:

1 - moss, lichen cover; 2 - peat, grass-wood; 3 - peat wood; 4 - peat, hypnum low moor; 5 - peat sedge-wood; 6 - peat, grass low moor; 7 - peat, grass-moss; 8 - peat moss; 9 - peat grass-hypnum, low moor; 10 - peat, sedge low moor; 11 - peat, Equisetum; 12 - peat, wood-equisetum; 13 - peat (a) and wood remains (b); 14 - loam; $15-{ }^{14} \mathrm{C}$ dates (years); 16 - assumed starting point of palsa formation

(the dates $7140 \pm 40 \mathrm{BP}, 6320 \pm 40 \mathrm{BP}$ ) and suggests that freezing and heaving commenced $6 \mathrm{ka}$ BP or later. The fourth palsa studied is about $4 \mathrm{~m}$ high and $7 \times 8 \mathrm{~m}$ in size (Fig. 5, a).

Transition from a subaqueous to a subaerial stage is distinguishable at a depth of
$0.8 \mathrm{~m}$. This stratum is marked by the replacement of predominant Equisetum and Menyanthes trifoliata remains by wood remains of birch and frutescent forms (Vaccinium) characterizing oligotrophic environments and dating back to $650 \pm 50 \mathrm{BP}$. The palsa surface commenced to heave in the period bet- 

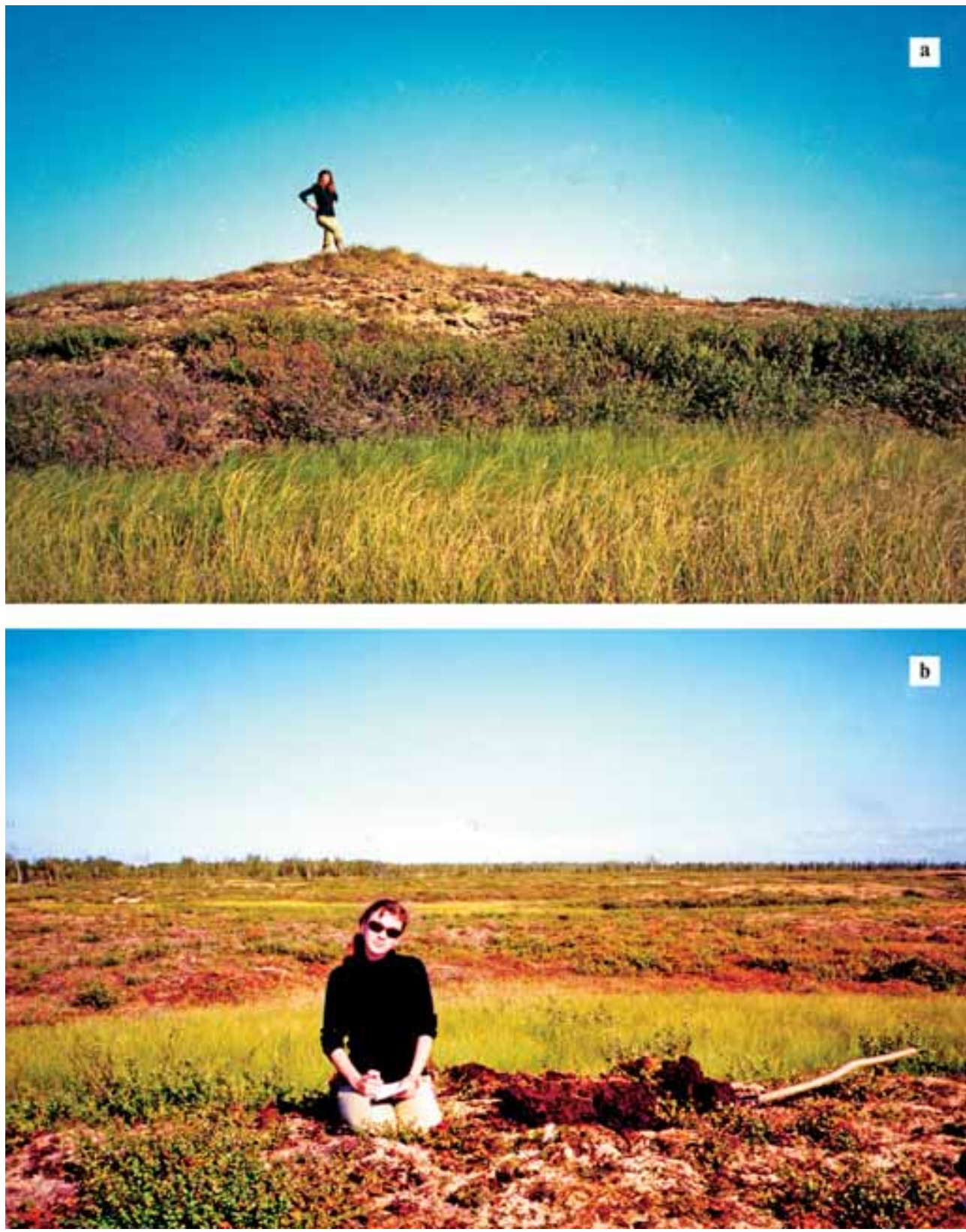

Fig. 4. Palsa mire near Usa settlement:

high (a) and small (b) palsa, Usa River valley

ween 6.5 and $6.0 \mathrm{ka}$ BP. This process was accompanied by the change of buckbean low-moor peat to peat containing woody remains of pine, willow and birch. The accumulation rate of the peat during the subaqueous stage was high, averaging $0.6 \mathrm{~m} / \mathrm{ka}$, whereas that in the subaerial stage was less than $0.1 \mathrm{~m} / \mathrm{ka}$.
Palsa mire near Abez' Settlement. The site is situated $1.2 \mathrm{~km} \mathrm{~N}$ of the Abez' Settlement $\left(66^{\circ} 31^{\prime} \mathrm{N}, 61^{\circ} 46^{\prime} \mathrm{E}\right), 100 \mathrm{~m} \mathrm{~N}$ of railway line, at $2098 \mathrm{~km}$ point of railway line Moscow Vorkuta. A large palsa mire with separate trees is located in the wood. Both high (up to $4 \mathrm{~m}$ - Fig. 2, b) and small (less than $1 \mathrm{~m}$ ) palsas of different age can be found here. 
Table 2. Radiocarbon dates of peat in palsas near Usa Settlement, North-eastern part of European Russia, Usa River valley

\begin{tabular}{|c|c|c|c|c|c|c|}
\hline $\begin{array}{l}\text { Radiocar- } \\
\text { bon dates } \\
\text { (BP) }\end{array}$ & $\begin{array}{c}\text { Laboratory } \\
\text { number }\end{array}$ & $\begin{array}{c}\text { Field num- } \\
\text { ber }\end{array}$ & $\begin{array}{l}\text { Depth, } \\
\text { m }\end{array}$ & Material & $\begin{array}{c}\text { Decom- } \\
\text { position } \\
\text { degree, \% }\end{array}$ & $\begin{array}{c}\delta^{13} \mathrm{C}, \\
\% \circ\end{array}$ \\
\hline \multicolumn{7}{|c|}{ Palsa, height $0.8 \mathrm{~m}$} \\
\hline $140 \pm 40$ & GIN-10976 & $383-Y u V / 2$ & 0.1 & Hypnum peat, & 5 & \multirow{4}{*}{-28.9} \\
\hline $780 \pm 40$ & GIN-10977 & $383-Y u V / 3$ & 0.25 & Wooden-sedge peat & 75 & \\
\hline $1890 \pm 80$ & Hel-4499 & $383-Y u V / 4$ & $0.3-0.35$ & $\begin{array}{l}\text { Grass-hypnum brown peat } \\
\text { with wood remains }\end{array}$ & 60 & \\
\hline $2090 \pm 40$ & GIN-10978 & $383-Y u V / 5$ & 0.4 & Grass-hypnum peat & $50-55$ & \\
\hline \multicolumn{7}{|c|}{ Palsa, height $2.0 \mathrm{~m}$} \\
\hline $3690 \pm 50$ & GIN-10979 & 383-YuV/11 & 0.4 & Grass low moor peat & 65 & \\
\hline \multicolumn{7}{|c|}{ Palsa, height $2.5 \mathrm{~m}$} \\
\hline $6320 \pm 40$ & GIN-10981 & 383-YuV/14 & 0.25 & Buckbean low moor peat & 55 & \\
\hline $7140 \pm 40$ & GIN-10980 & 383-YuV/13 & 0.5 & Sedge low moor peat & 85 & \\
\hline \multicolumn{7}{|c|}{ Palsa, height $4 \mathrm{~m}$} \\
\hline $5230 \pm 40$ & GIN-10982 & 383-YuV/15 & 0.3 & Wooden peat & 75 & \\
\hline $6490 \pm 110$ & Hel-4507 & $383-Y u V / 16$ & $0.6-0.7$ & Wooden peat & 55 & -29.5 \\
\hline $6650 \pm 50$ & GIN-10983 & $383-Y u V / 18$ & 0.8 & Buckbean, low moor peat & 60 & \\
\hline
\end{tabular}

Spots of naked peat are found on the surface of large palsas. Initial palsas are also found on inundated bog surface (Fig. 3, b). Their size is from $1 \times 1 \mathrm{~m}$ to $3 \times 5 \mathrm{~m}$, their height is not more than $0.5 \mathrm{~m}$. These palsas are often surrounded by a ring-like depression and platen. The pit of a large $3.0 \mathrm{~m}$ high palsa was investigated (Fig. 2, b). Its size is $20 \times 40 \mathrm{~m}$. There is no vegetation on the palsa surface. Lateral erosion destroyed the palsa. The following sediment sequence was observed from the top to the bottom of the palsa pit:

\section{0-0.3 m - Dry brownish-red peat}

$0.3-0.5 \mathrm{~m}$ - Wooden peat with twigs

$0.5-0.6 \mathrm{~m}$ - Dense peat with black vegetation remains

0.6-0.75 m - Dark brown peat with dark spots, pine and birch bark and shrub twigs

0.75-0.85 m - Loamy peat with wood $0.85-0.95 \mathrm{~m}-$ Frozen gray sandy loam.

Eight samples from the central part of the palsa have been ${ }^{14} \mathrm{C}$ dated (Table 3). From the results it can be established that the peat began to accumulate about $8.6 \mathrm{ka}$ BP. Peat accumulation was continuous about
5.6 ka during eutrophic conditions. Low moor horse tail peat changed to low moor sedge peat and further to grass peat with sequence remains of wood. Freezing and palsa growth began about $2.8 \mathrm{ka} \mathrm{BP}$. This is fixed in the pit with slightly decomposed moss and grass-moss peat with remains of grasses, Comarum palustre and Scheuchzeria palustris. Earlier two ${ }^{14} \mathrm{C}$ dates have been obtained from the bottom of the palsas in vicinity of Abez' (5600 \pm 70 and $6250 \pm 70 \mathrm{BP}$, MSU-429) [Evseev, 1986].

Comparison of pollen diagrams from palsa and the inter mound depression demonstrate that there are similarities in the pollen spectra from the lower part of depression and from the palsa. The pollen spectra from the palsa reflects that forest tundra was replaced with birch-spruce open woodland. Pollen spectra of spruce wood are found only in the upper part of the pollen diagram from the depression. This indicate that heaving began at the spruce wood stage.

Palsa mire near Nikita Settlement. In the Nikita Settlement area $\left(67^{\circ} 02^{\prime} \mathrm{N}, 63^{\circ} 48^{\prime} \mathrm{E}\right)$ there are 
Height,

m

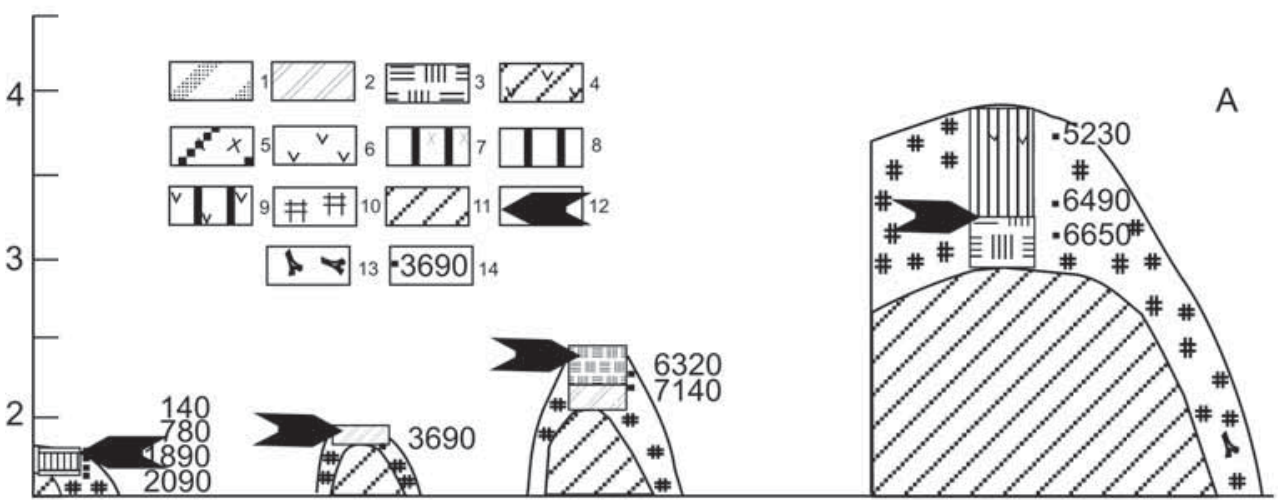

Height,

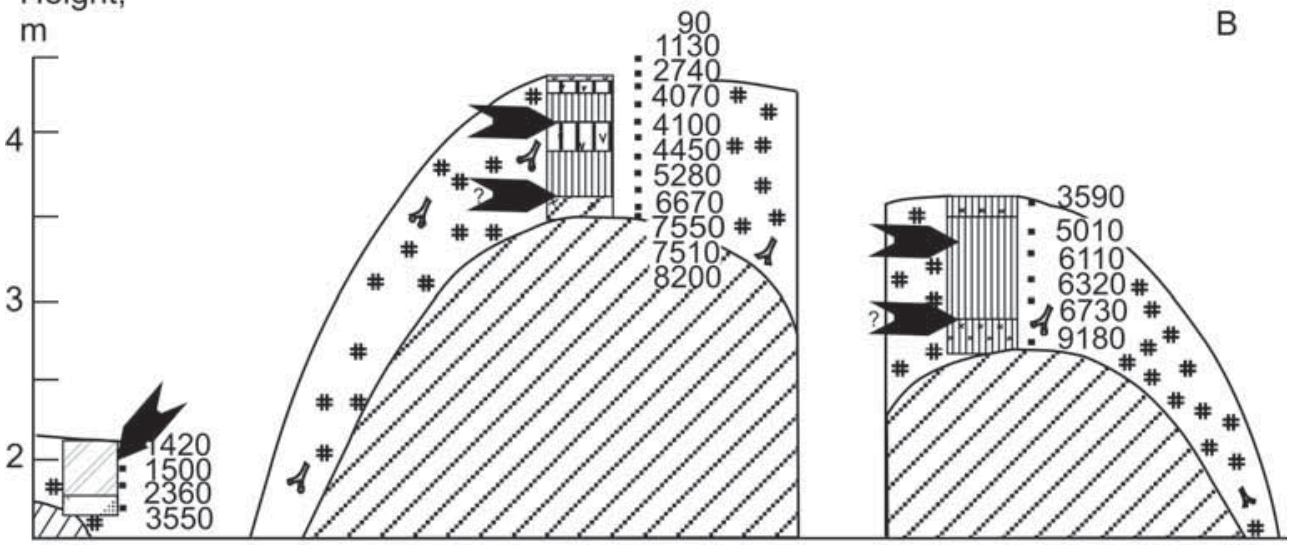

Height,

m

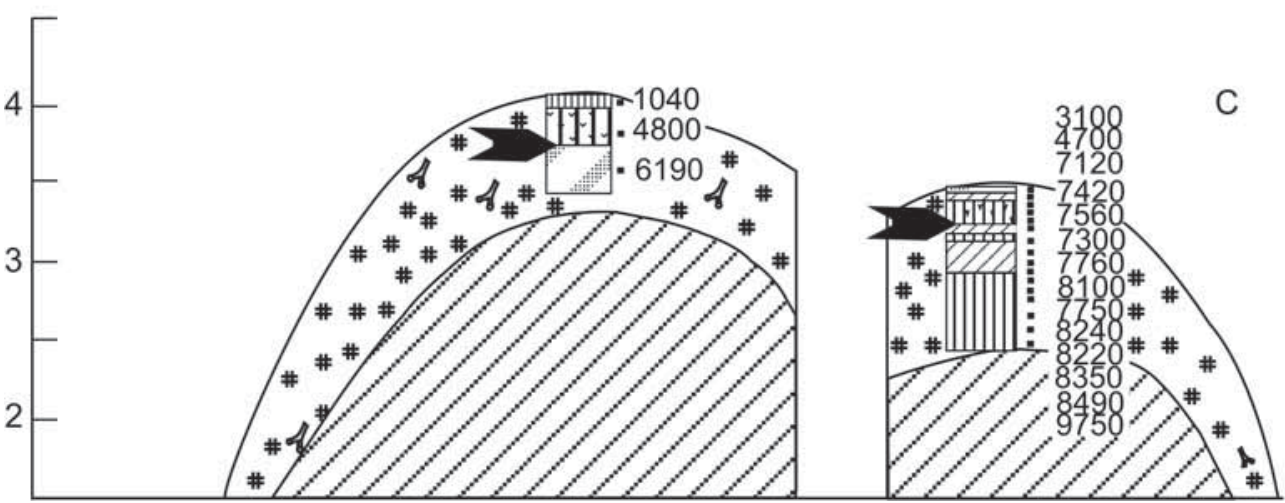

Fig. 5. Radiocarbon dated palsas near (A) Usa, (B) Nikita and (C) Eletskaya settlements, in Usa River valley:

1 - peat, sedge, low-moor; 2 - peat, sedge-hypnum; 3 - peat, buckbean, low-moor; 4 - peat, grass, low-moor; 5 - peat, equisetum, low-moor; 6- peat, high-moor; 7-peat, wood-equisetum; 8-peat wood; 9 - peat, grass-wood; 10 - peat; 11 - loam; 12 - assumed starting point of palsa formation; 13 - wood; $14-{ }^{14} \mathrm{C}$ dates (years) 
Table 3. Radiocarbon dates of peat in palsa near Abez' Settlement, North-eastern part of European Russia, Usa River valley

\begin{tabular}{|c|c|c|c|c|c|}
\hline $\begin{array}{c}\text { Radio- } \\
\text { carbon } \\
\text { dates (BP) }\end{array}$ & $\begin{array}{l}\text { Laboratory } \\
\text { number }\end{array}$ & $\begin{array}{l}\text { Field } \\
\text { number }\end{array}$ & $\begin{array}{l}\text { Depth, } \\
\text { m }\end{array}$ & Material & $\begin{array}{c}\text { Decom- } \\
\text { position } \\
\text { degree, \% }\end{array}$ \\
\hline $2710 \pm 40$ & GIN-11960 & 385-YuV/17 & $0.0-0.1$ & Peat, moss-grass & 10 \\
\hline $2760 \pm 40$ & GIN-11961 & 385-YuV/18 & $0.1-0.2$ & Peat, moss & 15 \\
\hline $2970 \pm 30$ & GIN-11962 & 385-YuV/19 & $0.2-0.3$ & Peat, hypnum-grass, low moor & 30 \\
\hline $3570 \pm 30$ & GIN-11963 & $385-Y u V / 20$ & $0.3-0.35$ & $\begin{array}{l}\text { Peat, grass-wood, with leaves, twig and bark } \\
\text { of birch, pine and willow }\end{array}$ & 25 \\
\hline $4050 \pm 30$ & GIN-11964 & 385-YuV/21 & $0.45-0.5$ & $\begin{array}{l}\text { Peat, grass with twigs and bark of birch, pine } \\
\text { and spruce }\end{array}$ & 20 \\
\hline $4590 \pm 30$ & GIN-11965 & 385-YuV/22 & $0.55-0.6$ & Peat, sedge, low moor & 25 \\
\hline $5050 \pm 40$ & GIN-11966 & $385-Y u V / 23$ & $0.65-0.75$ & $\begin{array}{l}\text { Peat, horstail low moor peat, with twig and } \\
\text { bark of birch, pine }\end{array}$ & 35 \\
\hline $5600 \pm 40$ & GIN-11967 & $385-Y u V / 24$ & $0.75-0.85$ & $\begin{array}{l}\text { Peat, horstail-wood with loam and bark of } \\
\text { birch, pine, at } 0.85 \mathrm{~m} \text { - loam }\end{array}$ & 45 \\
\hline
\end{tabular}
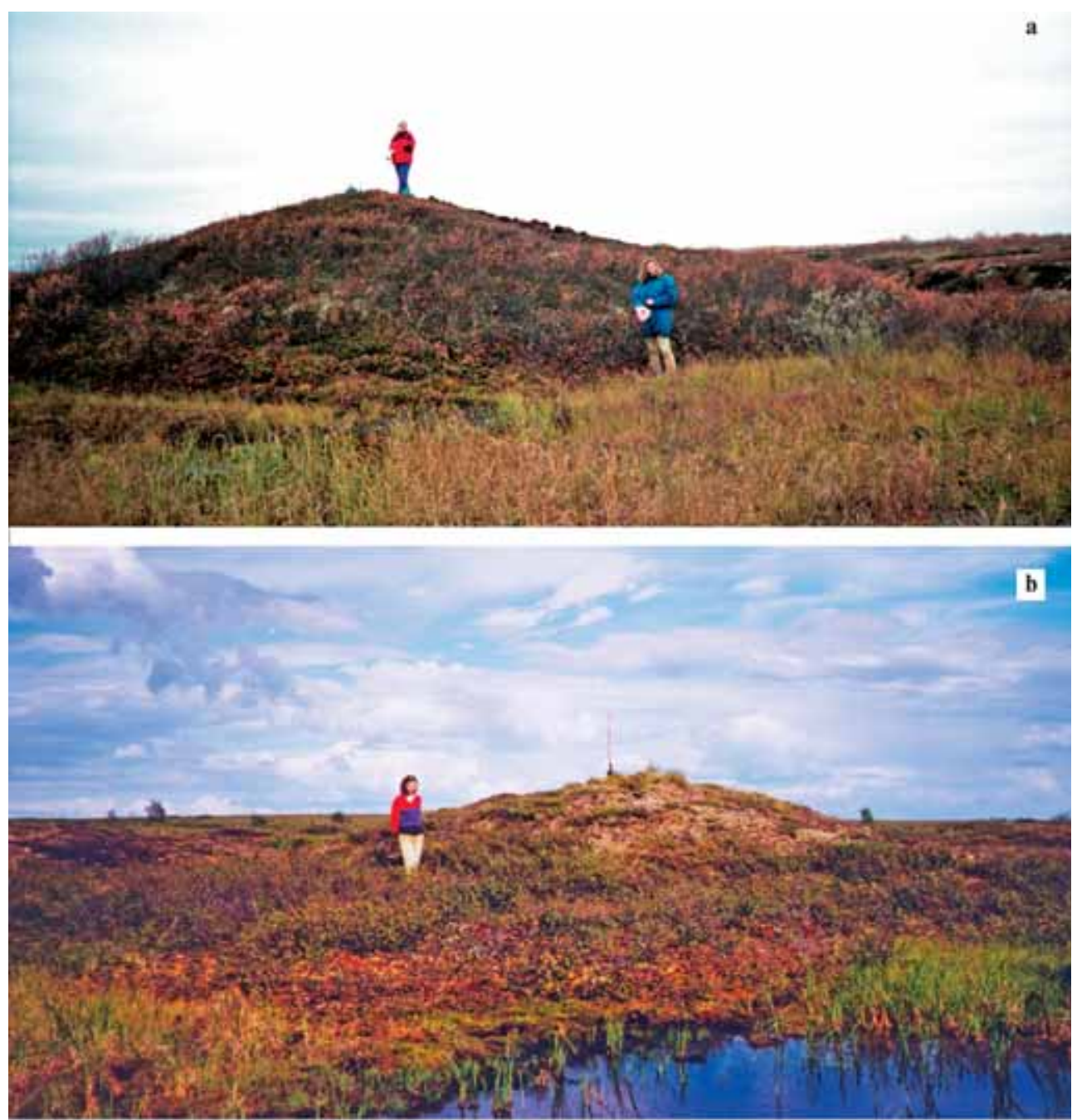

Fig. 6. Palsa mire near (a) Nikita and (b) Eletskaya settlements, Usa River valley 
both large (up to 5 and, even $8 \mathrm{~m}$ high) and smaller (up to $1.5-2.0 \mathrm{~m}$ high) palsas. The first palsa (4.7 $\mathrm{m}$ high) studied in this area is situated north of the Nikita railway station (Fig. 6, a). The total thickness of the peat overlying this palsa is $0.8 \mathrm{~m}$. Its section demonstrates transition from peat that formed in an environment of a bog covered by arboreal-horstail vegetation (depth interval of 0.8-0.65 m, dated at 8.2$6.7 \mathrm{ka} \mathrm{BP}$ - Fig. 5, b) to peat with high content of wood remains at a depth of $0.65 \mathrm{~m}$. At the beginning of the heaving process, the palsa surface was populated, along with arboreal forms, by sedges (Carex caespitosa, C. chordorrhiza, and C. diandra) and horsetails; the latter occur currently here in depressions located between palsas and resembling eutrophic swamps.

Consequently, $0.65 \mathrm{~m}$ of mainly woody peat accumulated during the subaerial stage. The rate of the palsa growth during the initial phase was sufficiently high and could reach the value of approximately $0.4 \mathrm{~m} / \mathrm{kyr}$. Subsequently, it decreased to about less than $0.1 \mathrm{~m} / \mathrm{kyr}$. The peat located at a depth of $0.25-0.35 \mathrm{~m}$ contains remains of buckbean (Menyanthes trifoliata), sedges (Carex chordorrhiza, C. diandra), and horsetail

Table 4. Radiocarbon dates of peat in palsas near Nikita Settlement, North-eastern part of European Russia, Usa River valley

\begin{tabular}{|c|c|c|c|c|c|c|}
\hline $\begin{array}{c}\text { Radio- } \\
\text { carbon } \\
\text { dates (BP) }\end{array}$ & $\begin{array}{l}\text { Laboratory } \\
\text { number }\end{array}$ & $\begin{array}{c}\text { Field } \\
\text { number }\end{array}$ & $\begin{array}{c}\text { Depth, } \\
\text { m }\end{array}$ & Material & $\begin{array}{c}\text { Decom- } \\
\text { position } \\
\text { degree, \% }\end{array}$ & $\begin{array}{c}\delta^{13} \mathrm{C}, \\
\% \circ\end{array}$ \\
\hline \multicolumn{7}{|c|}{ Palsa, height $4.7 \mathrm{~m}$} \\
\hline $90 \pm 70$ & Hel-4500 & $380-Y u V / 1$ & $0-0.03$ & Peat with lichens & $<5$ & \multirow[t]{3}{*}{-28.0} \\
\hline $1130 \pm 40$ & GIN-10621 & $380-Y u V / 2$ & $0.03-0.1$ & Wood-hypnacum peat & 80 & \\
\hline $2740 \pm 40$ & GIN-10622 & $380-Y u V / 3$ & $0.1-0.15$ & Wooden peat & $65-70$ & \\
\hline $4070 \pm 90$ & Hel-4501 & $380-Y u V / 4$ & $0.15--0.2$ & Wooden peat & 55 & \multirow[t]{3}{*}{-29.4} \\
\hline $4100 \pm 40$ & GIN-10623 & $380-Y u V / 5$ & $0.2-0.25$ & Wood-grass peat & 60 & \\
\hline $4450 \pm 40$ & GIN-10624 & $380-Y u V / 6$ & $0.25-0.35$ & Wood-grass peat with birch remains & 70 & \\
\hline $5280 \pm 100$ & Hel-4502 & $380-Y u V / 7$ & $0.35-0.45$ & Wooden peat & 60 & \multirow[t]{5}{*}{-29.4} \\
\hline $4890 \pm 40$ & GIN-10628 & $380-Y u V / 11$ & 0.5 & Birch & & \\
\hline $6670 \pm 40$ & GIN-10625 & $380-Y u V / 8$ & $0.45-0.55$ & Wooden peat, $65 \%$ & & \\
\hline $7550 \pm 50$ & GIN-10626 & $380-Y u V / 9$ & $0.55-0.65$ & Wooden peat -sedge & 75 & \\
\hline $7510 \pm 60$ & GIN-10627 & $380-Y u V / 10$ & $0.65-0.75$ & Horstail low moor peat & $65-70$ & \\
\hline $8200 \pm 130$ & Hel-4512 & $380-Y u V / 21$ & 0.75 & $\begin{array}{l}\text { Horstail low moor peat, with ice } \\
\text { lenses }\end{array}$ & 55 & -29.0 \\
\hline \multicolumn{7}{|c|}{ Palsa, height $3.5 \mathrm{~m}$} \\
\hline $3590 \pm 90$ & Hel-4503 & $380-Y u V / 12$ & $0.12-0.2$ & Brown peat with frutescent remains & 60 & -28.6 \\
\hline $5010 \pm 90$ & Hel-4508 & $380-Y u V / 13$ & $0.2-0.3$ & Wood-horstail peat & $45-50$ & -27.9 \\
\hline $6110 \pm 110$ & Hel-4509 & $380-Y u V / 14$ & 0.4 & Wood & & -25.5 \\
\hline $6320 \pm 90$ & Hel-4511 & $380-Y u V / 20$ & $0.4--0.5$ & Remains of large shrubs & & -25.4 \\
\hline $6730 \pm 100$ & Hel-4510 & $380-Y u V / 15$ & $0.55-0.6$ & Wooden peat & $45-50$ & -29.9 \\
\hline $9180 \pm 100$ & Hel-4504 & $380-Y u V / 16$ & 0.8 & Wood-horstail peat & $40-45$ & -28.6 \\
\hline \multicolumn{7}{|c|}{ Palsa, height $0.7 \mathrm{~m}$} \\
\hline $1420 \pm 120$ & GIN-10629 & $380-Y u V / 22$ & $0.1-0.15$ & Hypnum-sedge peat & $5-10$ & \multirow{4}{*}{-28.9} \\
\hline $1500 \pm 40$ & GIN-10630 & $380-Y u V / 23$ & $0.2-0.25$ & Hypnum-sedge peat & $60-65$ & \\
\hline $2360 \pm 90$ & Hel-4513 & $380-Y u V / 24$ & $0.3-0.35$ & Brown hypnum-sedge peat & 35 & \\
\hline $3550 \pm 40$ & GIN-10631 & $380-Y u V / 25$ & $0.5-0.55$ & Sedge low moor peat & 35 & \\
\hline
\end{tabular}


(Equisetum), which suggests partial thawing and subsidence of the palsa that occurred about 4.5 ka BP. Later, the palsa was restored and grew to its modern height. The second $3.5 \mathrm{~m}$ high palsa is situated approximately $1.5 \mathrm{~km}$ south of the Nikita Settlement.

The black-coloured wood-equisetum at the near-bottom peat with Betula remains at the base of section corresponds to a subaqueous stage of peat growth. This stage is dated to between $9180 \pm 100 \mathrm{BP}$ to $6730 \pm 100 \mathrm{BP}$ (Fig. $5, b$ ) and is marked by accumulation of low-moor peat and disappearance of arboreal vegetation due to swamping of this previously dry area. The palsa formation took place about 6.7 ka BP. Judging from the occurrence of horsetail remains in the peat, the partial thawing of the palsa took place approximately $5 \mathrm{ka}$ BP. The third palsa is small, $0.7 \mathrm{~m}$ high (Fig. 5, b). The botanical compo- sition of the peat cover allows recognition of the layer that corresponds to the stage of palsa surface oscillation relative to the bog surface and is marked by the replacement of low-moor sedge peat by the sedge-hypnum variety with occurrence of buckbean and grass in the depth interval $0.55-0.35 \mathrm{~m}$ and dated to 2.36-3.35 ka BP (Table 4). This palsa was quite unstable also during the period 2.3 to $1.4 \mathrm{ka}$ BP (according to dates $2360 \pm 90 \mathrm{BP}$ and $1420 \pm 120 \mathrm{BP})$.

Palsa mire near Eletskaya Settlement. A palsa mire is located $1.5 \mathrm{~km}$ to the north-east of the Eletskaya Settlement $\left(67^{\circ} 16^{\prime} \mathrm{N}, 63^{\circ} 39^{\prime} \mathrm{E}\right)$. The first palsa, $4 \mathrm{~m}$ high and $6 \times 7 \mathrm{~m}$ in size (Fig. 6, b), is overlain by a $1.15 \mathrm{~m}$ thick layer of peat. The commencement of heaving and termination of the subaqueous stage is observed at a depth of $0.3 \mathrm{~m}$. This level is dated to 4.8 ka BP (Fig. 5, c; Table 5). The subsequent

Table 5. Radiocarbon dates of peat in palsas near Yeletskaya Settlement, North-eastern part of European Russia, Usa River valley

\begin{tabular}{|c|c|c|c|c|c|c|}
\hline $\begin{array}{c}\text { Radio- } \\
\text { carbon } \\
\text { dates (BP) }\end{array}$ & $\begin{array}{l}\text { Laboratory } \\
\text { number }\end{array}$ & $\begin{array}{c}\text { Field } \\
\text { number }\end{array}$ & Depth, m & Material & $\begin{array}{c}\text { Decom- } \\
\text { position } \\
\text { degree, \% }\end{array}$ & $\begin{array}{c}\delta^{13} C, \\
\% \circ\end{array}$ \\
\hline \multicolumn{7}{|c|}{ Palsa, height $4 \mathrm{~m}$} \\
\hline $1040 \pm 50$ & GIN-10968 & 382-YuV/17 & 0.15 & Peat with frutescent remains & 20 & \\
\hline $4800 \pm 50$ & GIN-10969 & 382-YuV/18 & 0.3 & Wood-sedge peat & 60 & \\
\hline $6190 \pm 40$ & GIN-10970 & 382-YuV/19 & 0.6 & Sedge peat & $25-30$ & \\
\hline \multicolumn{7}{|c|}{ Palsa, height $3.5 \mathrm{~m}$} \\
\hline $3100 \pm 40$ & GIN-10971 & $382-Y u V / 1$ & 0.05 & Sedge peat & 80 & \\
\hline $4700 \pm 50$ & GIN-10972 & $382-Y u V / 2$ & 0.1 & Grass-sedge peat & 65 & \\
\hline $7120 \pm 100$ & Hel-4518 & $382-Y u V / 3$ & $0.1-0.15$ & $\begin{array}{l}\text { Brown wood-grass peat with } \\
\text { twigs }\end{array}$ & 65 & -28.9 \\
\hline $7420 \pm 110$ & Hel-4519 & 382-YuV/4 & $0.15-0.2$ & Wood-sphagnum peat & $65-70$ & -28.1 \\
\hline $7560 \pm 90$ & Hel-4520 & $382-Y u V / 5$ & $0.2-0.25$ & $\begin{array}{l}\text { Grass-hypnum peat with } \\
\text { wood remains }\end{array}$ & $30-35$ & -28.4 \\
\hline $7300 \pm 40$ & GIN-10973 & $382-Y u V / 6$ & 0.3 & Grass-hypnum peat & 60 & \\
\hline $7760 \pm 110$ & Hel-4527 & 382-YuV/7 & $0.35-0.45$ & Hypnum peat & 30 & -29.3 \\
\hline $8100 \pm 90$ & Hel-4528 & 382-YuV/8 & $0.45-0.5$ & Wooden peat & 30 & -29.5 \\
\hline $7750 \pm 40$ & GIN-10974 & $382-Y u V / 9$ & 0.6 & Grass, low moor peat & 45 & \\
\hline $8240 \pm 90$ & Hel-4529 & $382-Y u V / 10$ & $0.65-0.75$ & Wooden peat & 40 & -30.2 \\
\hline $8220 \pm 110$ & Hel-4521 & 382-YuV/11 & $0.75-0.8$ & Wooden peat & $60-65$ & -29.6 \\
\hline $8350 \pm 110$ & Hel-4505 & $382-Y u V / 12$ & $0.8-0.82$ & Frozen peat & & -27.9 \\
\hline $8490 \pm 70$ & GIN-10975 & $382-Y u V / 13$ & 0.9 & Wooden peat with sand & 75 & \\
\hline $9750 \pm 160$ & Hel-4506 & $382-Y u V / 14$ & 1.15 & Peat with ice lens & & -29.3 \\
\hline
\end{tabular}


subaerial stage lasted less than 5000 yrs and peat with Vaccinium sp., Chamaedaphne calyculata and Carex vesicaria accumulated with the average rate of $0.06 \mathrm{~m} / \mathrm{kyr}$. The botanical composition of a $0.9 \mathrm{~m}$ thick peat layer overlying a $3.5 \mathrm{~m}$ high palsa indicates that its surface was first covered by arboreal vegetation (Betula sect. Albae) and was then flooded. In the interval 0.25 to $1.15 \mathrm{~m}$ peat of the subaqueous stage is marking the stage of low-moor bog. As a result of subaqueous development, arboreal vegetation was replaced by a low-moor herbaceous one dominated by Menyanthes trifoliata, Carex diandra, C. chordorrhiza. This stage is dated to 9.7 to $7.56 \mathrm{ka}$ BP (Fig. 5, c). The palsa summit shows also the presence of low-moor sedge peat, which might suggest partial thawing during the period of about 4.7 to $3.1 \mathrm{ka} \mathrm{BP}$ (according to dates $3100 \pm 40 \mathrm{BP}$ and $4700 \pm 50 \mathrm{BP}$ from low moor peat).

Palsa near Khanovey Settlement. A single palsa $20 \times 40 \mathrm{~m}$ and $3 \mathrm{~m}$ high (Fig. 7) was found in $2 \mathrm{~km} S$ of the Khanovey Settlement, $25 \mathrm{~km} \mathrm{S-W}$ of the Vorkuta town, at the $2233 \mathrm{~km}$ point of railway line Moscow Vorkuta. There is naked peat on it summit, as indicator of initial destruction. Typical high moor vegetation covers the palsa (Ledum palustre, Oxycoccus sp., et al.)

The following sediment sequence was observed from the top to the bottom of the palsa:

0.0-0.03 m - Dry moss cover

0.03-0.08 m - Dark brown peat with rootlets 0.08-0.2 m - Dark brown wet peat

$0.2-0.3 \mathrm{~m}$ - Brown peat

0.3-0.7 m - Dark brown frozen peat

$0.75-0.8 \mathrm{~m}$ - Light brown peat with remains of aquatic plants

0.8-0.85 m - Brown icy peat.

The pit on the palsa slope has following sequence of sediments:

0.0-0.07 m - Dry moss cover

0.07-0.2 m - Dark brown peat with rootlets

$0.2 \mathrm{~m}-0.3 \mathrm{~m}$ - Frozen dark brown peat with rootlets

From $0.3 \mathrm{~m}$ - Frozen grayish loam.

The pit at the basis of palsa has following sequence of sediments:

0.0-0.15 m - Black peat with rootlets from $0.15 \mathrm{~m}$ - Frozen grayish-brown loam.

Six samples from the center of the palsa were ${ }^{14} \mathrm{C}$ dated (Fig. 8). The results indicate that the peat began to accumulate about 8.8 ka BP (Table 6).

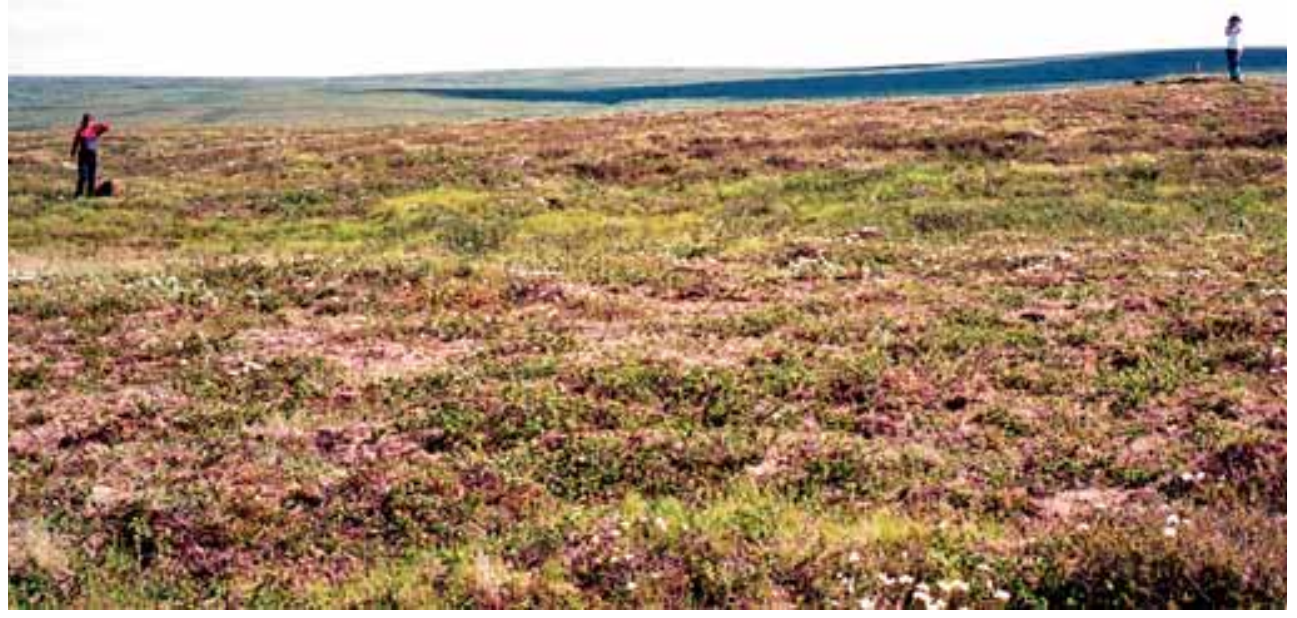

Fig. 7. Palsa mire near Khanovey settlement, Vorkuta area 


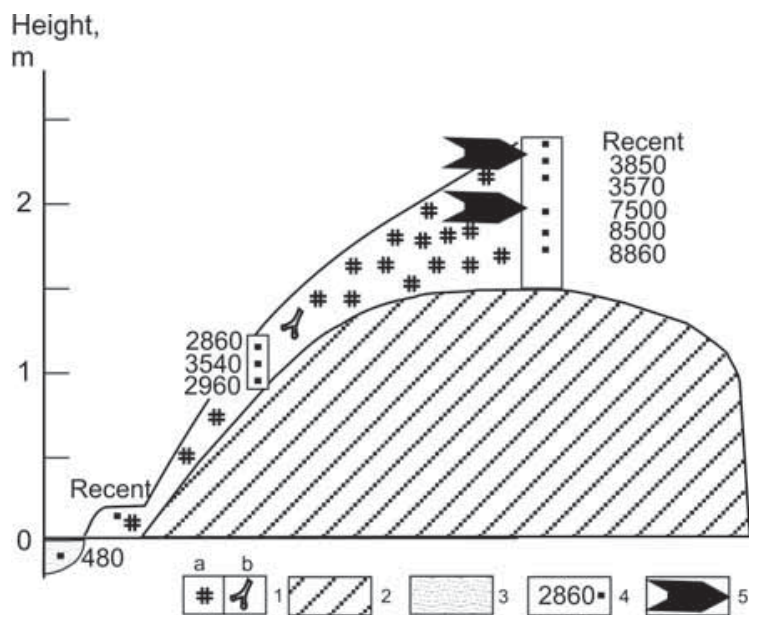

Fig. 8. Radiocarbon dated palsa of Northeast Europe, Vorkuta area, near Khanovey settlement: 1 - peat (a) and wood remains (b); 2 - loam; 3 - pond near palsa, water; $4-{ }^{14} \mathrm{C}$ dates (years); 5 - assumed starting point of palsa formation

Peat accumulation was continuous about 1.3 ka at eutrophic conditions. Low moor light brown peat with remains of aquatic plants accumulated at that time. Then from 7.5 to $3.5 \mathrm{ka}$ BP peat accumulation ceased because the mire was frozen and palsa formed. A short resumption of peat accumulation took place about 3.5 ka BP. ${ }^{14} \mathrm{C}$ dating of 3 samples from a pit at the slope of the palsa show that the peat at that point is younger than peat in the central part of the palsa. The thickness of the peat layer is not more than $0.25 \mathrm{~m}$ and the dates are about 2.9-2.8 ka BP. There is also an inversion of dates such that a

Table 6. Radiocarbon dates of peat in palsa near Khanovey Settlement, North-eastern part of European Russia, Vorkuta area

\begin{tabular}{|c|c|c|c|c|}
\hline $\begin{array}{l}\text { Radiocarbon } \\
\text { dates (BP) }\end{array}$ & $\begin{array}{l}\text { Laboratory } \\
\text { number }\end{array}$ & $\begin{array}{l}\text { Field } \\
\text { number }\end{array}$ & Depth, m & Material \\
\hline \multicolumn{5}{|c|}{ Pit at the top of the palsa, height $2.5 \mathrm{~m}$} \\
\hline Recent & GIN-12072 & 393-YuV/1 & $0.0-0.05$ & Peat \\
\hline $3850 \pm 40$ & GIN-12073 & 393-YuV/3 & $0.1-0.2$ & Peat \\
\hline $3570 \pm 40$ & GIN-12074 & $393-Y u V / 4$ & $0.2-0.3$ & Peat \\
\hline $7500 \pm 40$ & GIN-12075 & 393-YuV/7 & $0.4-0.5$ & Peat, frozen \\
\hline $8500 \pm 60$ & GIN-12076 & 393-YuV/10 & $0.6-0.65$ & Peat, frozen, dark brown \\
\hline $8860 \pm 40$ & GIN-12077 & 393-YuV/20 & $0.65-0.7$ & $\begin{array}{l}\text { Peat, frozen, light brown with aquatic } \\
\text { plants remains }\end{array}$ \\
\hline \multicolumn{5}{|c|}{ Pit at the slope of the palsa } \\
\hline $2860 \pm 30$ & GIN-12078 & 393-YuV/11 & $0.07-0.15$ & Peat dark brown with rootlets \\
\hline $3540 \pm 40$ & GIN-12079 & 393-YuV/12 & $0.15-0.2$ & Peat dark brown \\
\hline $2960 \pm 40$ & GIN-12080 & 393-YuV/13 & $0.2-0.25$ & Peat frozen brown at the contact of loam \\
\hline \multicolumn{5}{|c|}{ Pit at the basement of the palsa } \\
\hline Recent & GIN-12081 & 393-YuV/14 & $0.05-0.15$ & Peat, black with rootlets \\
\hline \multicolumn{5}{|c|}{ Pit in inundated depression near the palsa basement } \\
\hline $480 \pm 50$ & GIN-12082 & 393-YuV/17 & 0.2 & Hummock \\
\hline
\end{tabular}


date of $3.5 \mathrm{ka}$ BP is located between the two dates of 2.9 and $2.8 \mathrm{ka}$ BP. Date inversions are rare for the palsas in this area. This inversion is caused by peat moving down the slope. The youngest dates, $480 \mathrm{BP}$ and a recent one, were obtained from peat at the basement of the palsa and in an inundated depression around the palsa. This is the first case with such a distribution of ${ }^{14} \mathrm{C}$ dates. The old ${ }^{14} \mathrm{C}$ dates are obtained from peat in the central part of the palsa and younger dates are from peat at the slope. This evidences that this palsa is a result of frost heaving but has not been flattened by erosion [e.g. P'yavchenko, 1955].

The initial heaving took place around $7.5 \mathrm{ka} \mathrm{BP}$ and a secondary heaving from 3.5 to $2.8 \mathrm{ka}$ BP. In the surrounding depression peat accumulated up to $2.8 \mathrm{ka}$ BP. As a result a $3 \mathrm{~m}$ high palsa more than $45 \mathrm{~m}$ in diameter had been formed.

\section{DISCUSSION}

Initial point of palsa formation. The initiation of palsa formation as a topographical structure can best be evaluated from the radiocarbon age of peat formed at the period when the palsa surface appears above the water table of a surrounding bog (more exactly, the surface of seasonal thawed layer at the top of a palsa). In different zones the starting point of palsa formation appears to be very similar. The rate of palsa growth during the initial phase is sufficiently high, but after heaving peat accumulation slows down and finally ceases.

Dynamics of palsa development in the Holocene. It is assumed that the Holocene optimum covering about two thirds of the first half of Holocene was period of general permafrost degradation and the decay of most of palsa. But the research of the authors of this article showed that it is not absolutely true.

H. Seppa with colleagues [Välliranta et al., 2010, Salonen etal.,2011] studied the changes in the wood vegetation during Holocene at palsa massifs in Bolshezemelskaya tundra,
Pechora River basin. They assume that the expansion of the natural areas of wood vegetation (spruce, birch) occurred at this region (currently located at the timberline and outside it) during the Holocene optimum. The vegetation grew here as isolated rare forests since the beginning of the Holocene [Välliranta et al. 2010]. During the Holocene optimum which was defined here between 8.0 and $3.5 \mathrm{ka}$ BP the summer mean temperature in tundra was $3^{\circ} \mathrm{C}$ higher than the nowadays [Salonen et al., 2011]. Spruce forests were growing at that time around the Khariney Lake located $150 \mathrm{~km}$ to the north from the modern timberline. The temperature decreased about 3.5-2.5 ka BP that led to an active aggradation of permafrost and intensive palsa growth as well as wood vegetation extinction. The most ancient remains of the vegetation dated about $2.5 \mathrm{ka}$ [Salonen et al., 2011].

T. Jaworski and W. Niewiarowski [2012] studied late Holocene palsa formed within a network of ice-wedge polygons on Hermansenøya, NW Svalbard. They occur in the part of the peat bog that is always better drained than other parts of the bog. The height of palsa vary from 0.2 to $1.3 \mathrm{~m}$, the thickness of the peat cover reaches 32 $37 \mathrm{~cm}$, but the total thickness of the peat in the examined mound reaches about $50 \mathrm{~cm}$, while on the peat bog it is $25-40 \mathrm{~cm}$. The radiocarbon dates of the peat suggested that a low $(0.4-0.5 \mathrm{~m})$ frost peat mound was formed during the considerable climate cooling in the period around 3.0-2.5 ka BP. Its formation and survival until today correspond to the formation and survival of pingos and ice wedges in Adventdalen (central Spitsbergen) and of the oldest palsas in northern Finland and on the Kola Peninsula [Jaworski, Niewiarowski, 2012].

According to J. McLaughlin and K. Webster [2013] palsa of Hudson Bay Lowlands the largest peatland complex with the southernmost distribution of non-alpine permafrost in North America - started to grow primarily during the Little Ice Age when permafrost aggradation occurred in 
this region. Peat accumulation began much ealier: the $14 \mathrm{C}$ dates of bottom peat of palsa vary from 6.9 to $4.6 \mathrm{ka}$ yr [McLaughlin, Webster, 2013].

The radiocarbon dating carried out by the authors allowed to define the beginning of heaving and the dynamics of palsa in the Holocene at the areas near the Bugry Station and Usa, Abez, Nikita, Eletskiy and Khanovey settlements. Calculations show that the heave processes within the areas are caused both by general climatic changes and local factors. Peat accumulation rate, periods of heaving and the duration of the
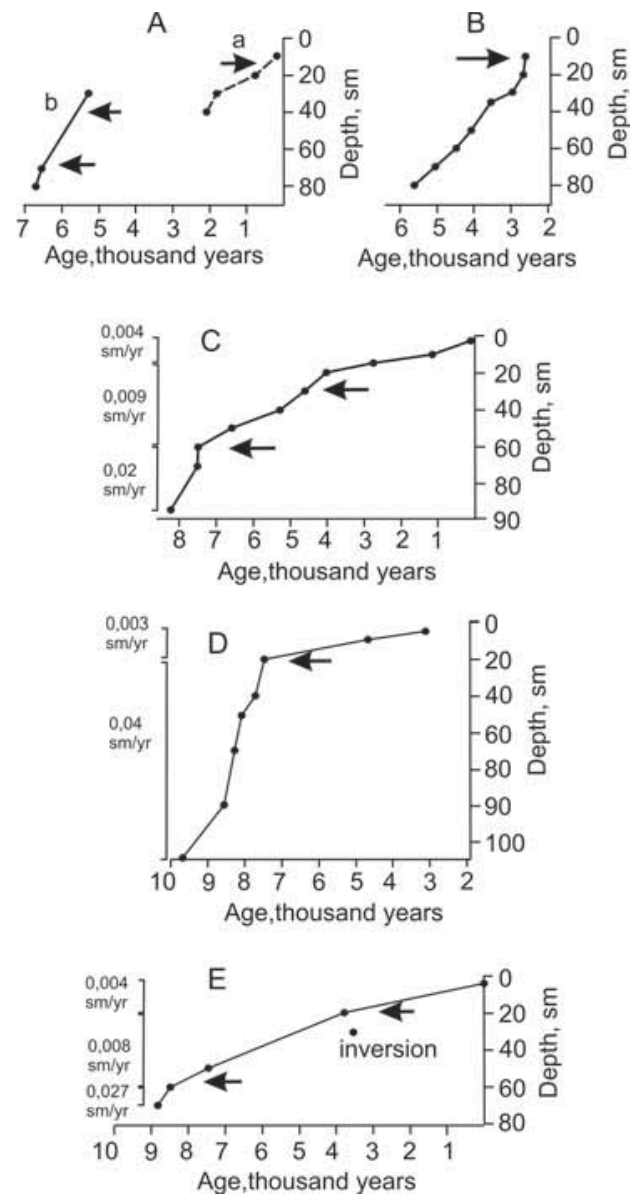

Fig. 9. Assumed heave events (shown with arrows) and the rate of peat accumulation in palsa of Bolshezemelskaya tundra:

$A$ - Usa settlement, $B$ - Abez settlement, $C$ - Nikita settlement, D-Eletskiy settlement, E-Khanovey settlement subaerial and the subaquatic phases can be different within the same massif. Nonetheless, the stages of the intensification and relative fading of heave processes can be identified based on a large data. Permafrost did not degrade and, on contrary, the formation of new palsa could begin during the Holocene optimum even within the southern part of the permafrost area. Intensive peat accumulation as a result of high summer temperatures and the same winter severity (locally more severe than present) during the Holocene optimum was the main factor of this phenomenon that at first glance can seem a geocryological antinomy. Let us describe the dynamics of the studied palsa in more detail.

Bugry Station. It was found that at the initial stage the growth of a minor palsa $0.8 \mathrm{~m}$ high near the Bugry station repeatedly ceased. It was evidently formed during the recent century, since the age of the sample from $0.1 \mathrm{~m}$ depth and that of the sedge-hypnum peat from the surface is approximately 140 years (Fig. 9A). The formation of another palsa about $2 \mathrm{~m}$ high started not earlier than 3.7 ka BP. Since sedge-hypnum peat beds at the surface, it can be assumed that the heaving process was quite fast. This is associated with the fact that the high-bog peat did not have enough time to form. Since there is no lichenous cover on palsa, it can be assumed that heaving occurred not long ago (within the recent 100 years).

Change of sedge lowland peat 7.10 ka BP (at $0.5 \mathrm{~m}$ depth) to lowland buck-bean peat $6.32 \mathrm{ka} \mathrm{BP}$ is found in the section of palsa $2.5 \mathrm{~m}$ high. This indicates the activated process of the change of the water-mineral supply regime between 7.1 and $6.3 \mathrm{ka} \mathrm{BP}$. According to radiocarbon dates and peat composition, heaving occurred here not earlier than $6 \mathrm{ka}$ BP. The formation of palsa about $4 \mathrm{~m}$ high began not earlier than 6.5-6.0 ka BP. At the same time the buckbean lowland peat was replaced by the wood peat with residuals of pine, willow and birch. The peat accumulation rate during the subaquatic phase was quite high -0.06 $\mathrm{cm} / \mathrm{yr}$. According to the correlation of dates 
and the peat layer thickness, the transition to the subaquatic phase finished about $5 \mathrm{ka}$ BP. At that time peat accumulation and palsa growth ceased completely.

Usa Settlement. The heaving process near Usa settlement was most intensive after 6.5$6.0 \mathrm{ka}$ BP. The palsa rose above the surface by 2-3 $\mathrm{m}$. Some of palsa formed at that time now begin to decay. However, the active heaving process started again 3.7-2.1 ka BP and is still going on. The uplift of the younger palsa surface consists of 0.35-1.60 m (Fig. 9A).

Abez' Settlement. The formation of palsa near Abez' settlement started about 2.7 ka BP. This is identified by transition to the young, i.e. quickly freezing, transient moss and mossgrass peat with the remains of scheuchzeria, herbs and cowberry (Fig. 9B).

Nikita Settlement. The formation of palsa $4.7 \mathrm{~m}$ high near Nikita settlement started about $7.5 \mathrm{ka} \mathrm{BP}$, according to replacement of the lowland bog peat by peat with high content of wood remains (which probably indicates partial site drying, Fig. 9C). Heaving took a long time according to peat accumulation rate. The transient phase finished about $2.7 \mathrm{ka}$ BP. Buck-bean (Menyanthes trifoliata), sedge (Carex chordorrhiza, C. diandra) and horsetail (Equisetum) remains are found at the depth of $0.25-0.35 \mathrm{~m}$. This can evidently indicate the partial thawing and subsidence of the palsa about $4.5 \mathrm{ka}$ BP. Later it recovered again and grew till the current size. Palsa $3.5 \mathrm{~m}$ high started forming about $6.7 \mathrm{ka}$ BP. This is identified by replacement of black woodhorstail near-bottom peat by with remains of wood and large bushes. Partial thawing of palsa probably occurred approximately $5 \mathrm{ka}$ BP, according to horsetail remains in the peat at the depth of $0.2-0.3 \mathrm{~m}$. Then palsa recovered again (not earlier than $3.6 \mathrm{ka}$ $\mathrm{BP}$ ). A minor palsa $0.7 \mathrm{~m}$ high composed of peat accumulated in conditions of intensive flooding of the site began growing about $2.3 \mathrm{ka}$ BP. This was defined by replacement of sedge lowland peat with sedge-hypnum peat containing buck-bean and herbs. The heave was extremely unstable: it evidently thawed and subsided repeatedly (it is most probable that only a low hillock or a hummock remained after the subsidence). Then it froze and heaved again. But after 1.5$1.4 \mathrm{ka}$ BP this pulsating state was transformed to a more stable one.

Eletskiy Settlement. The beginning of heaving and termination of the subaquatic phase of palsa development was identified in the section of the $4 \mathrm{~m}$ high palsa near Eletskiy settlement at $0.3 \mathrm{~m}$ depth, and it was dated as $4.8 \mathrm{ka}$ BP. The next subaerial phase lasted for about $5 \mathrm{ka}$. The formation of palsa $3.5 \mathrm{~m}$ high evidently occurred 7.5 ka BP. The rate of peat accumulation during subaquatic phase was $0.27 \mathrm{~m} / \mathrm{ka}$ (Fig. 9D). The peat accumulation rate during the subsequent subaerial phase was $0.08 \mathrm{~m} / \mathrm{ka}$. Sedge lowland-type peat is found on the palsa top. This can indicate a partial thawing of palsa 4.7-3.1 ka BP. It can be assumed that the heave process near Eletskiy settlement occurred most intensively about 7.7 ka BP when palsa grew by 3.0-3.4 m.

Khanovey Settlement. The dating of the peat from palsa near Khanovey settlement showed a long gap in peat accumulation or steep slowing down of the peat formation process 7.5-3.5 ka BP. This testifies to the massif's freezing and the formation of a comparatively low palsa. Peat accumulation resumed for a short period about 3.5 ka BP. Since a recent date was received for the palsa top (the peat accumulation is still going on), it is evident that palsa uplifted above the surface not long ago (Fig. 9E). The distribution of radiocarbon dates in palsa section (more ancient in the axial part and younger on the slope) demonstrated two important points. Firstly, this land form is properly palsa, it is not a residual form occurred as a result of the erosion of an initially flat peatland. Not only the followers of the hypothesis of the erosional origin of palsa at this area thought so. It was also acknowledged by the researchers who principally recognized heaving as the main mechanism of palsa like forms, but thought that in the Bolshezemelskaya tundra this 
process take place in more southern areas, while the heave terrain forms that occurred in the north, near Vorkuta, in the conditions of lower ground temperatures were referred to residual large-block forms generated as a result of erosion in frost cracks. Secondly, both the initial moment of heaving $7.5 \mathrm{ka}$ $\mathrm{BP}$ and the moment of secondary additional heaving approximately 3.5-2.8 ka BP are clearly observed here. At the moment of initial heaving a minor palsa several meters in diameter and probably no more than 1.0-1.5 m high was formed. At the moment of secondary heaving a palsa more than $3 \mathrm{~m}$ high and more than $45 \mathrm{~m}$ in diameter was formed from the initially small one. It covered the surrounding flooded depression where peat accumulation occured $2.8 \mathrm{ka}$ BP but then stopped after heaving.

Usa River Valley. Palsa mires in Usa River valley developed in several stages. Palsa 3.5-5.0 m high were formed 7-6 ka BP. The height of the peatlands' surfaces at that time reached 2.25-4.0 m. Smaller palsa were formed 3.5$2.0 \mathrm{ka}$ BP. Their height was $0.35 \mathrm{~m}$.

In Northern Finland Seppälä [1971, 2011] has found similar appreciable difference between radiocarbon dates of peat from palsa and its immediate vicinity as we obtained for palsas in Usa River valley. In a cross-sections of a peat plateau at the Rogovaya River (about $62 \mathrm{~km}$ to the north from Abez', $50 \mathrm{~km}$ southwest from Khanovey), the transition from sedge peat to Sphagnum peat is dated to about $3 \mathrm{ka} \mathrm{BP}$ (3120 \pm 100, Hel-3796) [Oksanen et al., 1998]. The transition probably marks the beginning of freezing and elevation of surface. Ortino peat plateau near Pechora delta began to develope after 4800 BP [Väliranta et al., 2003, 2010] when Sphagnum fuscum peat changed by Sphagnum rossowii peat.

In the Bygristoe bog in central part of Western Siberia palsa formed in Holocene according to pollen data and botanical composition of peat [Blyakharchuk, Sulerzhitsky, 1999]. The wet-plant mire communities with Menyanthes trifoliate, which grows only in wet unfrozen mire, were replaced by vegetation of relatively dry mire conditions; Pinus sibirica forest with dwarf mire shrubs and moss (Chamaedaphne caliculata, Ledum palustre, Vaccinium vitis-idaea, Vaccinium myrtillus) as a result of freezing and heaving of peat. The transition is dated to $4740 \pm$ $\pm 100 \mathrm{BP}(\mathrm{GIN}-5517)$. The increase of seasonality about 4300 BP caused Bugristoe bog to freeze, the accumulation of peat slowed down and ceased. This event coincided with the end of Abies forests and spread of pure Pinus sibirica forests in the taiga of Western Siberia.

Age of palsa growth and collapse. The radiocarbon dates shown in Table 1, and also dates from other areas in the permafrost zone of Russia suggests that the age of palsas is almost independent of latitude and temperatures of the permafrost. It seems that heaving processes are controlled by both general climatic changes and local factors even within a small area. The heaving process in the Usa River Valley was most intense in the period from 7.5 to $6.2 \mathrm{ka} \mathrm{BP}$. Substantial activation of the heaving process occurred 3.7-1.4 ka BP and resulted in intense formation of younger palsas, which continue to grow rapidly until today. At present, new palsas are observed in some draining areas.

In Laivadalen (Sweden) most of the palsas started to grow in the period 1520 to 1730 AD (390 \pm 70 BP, Ua-13229; $95 \pm 65$ BP, Ua13228; and $105 \pm 65$ BP, Ua-13230). However, oligotrophic peat with Sphagnum remains dated to $8150 \pm 85$ BP (Ua-13227) has been found, which indicates that the palsa is older than $8000 \mathrm{yr}$. The dating from Laivadalen in combination with the climate records suggest a very young age, possibly as late as the cold period around 1860-1890; the longest cold period since 1721 in the Uppsala, southern Sweden, temperature record [Zuidhoff, Kolstrup, 2000]. New ${ }^{14}$ C-datings of peat of interfluve areas and joint analysis of the dynamics of the mire systems and permafrost conditions of Bolshezemel'skaya tundra in Holocene [Maksimova, Ospennikov, 2012] demonstrated close matching with our results. They have shown that active 
growth of palsa in this region was preceded process of mire evolution about 8.5-4.5 ka $\mathrm{BP}$ as a result of permafrost degradation. About 4.5 ka BP a climate cooling has begun as well as process of change fen bogs by high bogs. Permafrost aggradation in bogs was accompanied by palsa formation. High bogs were wide spread at this stage and their cooling effect protected permafrost from long-term thawing during the warming periods [Maksimova, Ospennikov, 2012].

Heaving caused both global climatic changes and local factors. It has different appearance even within single palsa array due to differentiation of the moment of initial heaving, accumulation rate of the peat, duration of subaqueous and subaerial stages. Certain of the palsa grow and collapsed cyclically. Surface thermokarst leds to erosion, flash of palsas, but and subsequent drainage leds to young palsa formation. Similar palsa often observes in the north of Canada [Lewkowicz, Coultish, 2004] and in Scandinavia [Seppälä, 2011].

V. Barcan studied palsa near their southern boundary in the Cola Peninsula [Barcan, 2010] (up to $67^{\circ} 55^{\prime} \mathrm{N}$ in Nyudo Lake and $67^{\circ} 57^{\prime} \mathrm{N}$ in Monche Lake, Lumbolka Lake, Imandra Lake). It was found that most part of palsa did not thawed during last 80 years in spite of annual temperature variation from $-3.0^{\circ} \mathrm{C}$ to $+2.8^{\circ} \mathrm{C}$. Relief features favor to conservation and modern growth of the palsa in Nyudo Lake area located between Nyud and Sopchel Mountains. Strong winter wings blow off the snow cover from mire surface. The same situation is observed in the other palsa mires which are located along to main direction of the winter wings [Barcan, 2010]. Near Umbozero Lake (Kola Peninsula) palsas started to grow about $4.5 \mathrm{ka}$ yr BP and now they are in the stable state even in the "warm" permafrost [Romanenko, Garankina, 2012]

The wooded palsas at the treeline of the Rivière Boniface, Canada, were formed during two different periods of the last millennium between 750 and 1000 AD and during the 1500s. The maintenance of a permafrost mound under forest cover is a rare situation in northern environments, and wooded palsas in eastern Canada form peculiar ecosystems where forest and permafrost coexist; these have survived over the last 500 to 1000 years. According to S. Cyr and S. Payette [2012] the inception of wooded palsas was facilitated during a prolonged period of snow-poor winter conditions. Tree establishment was possible due to well-drained soil conditions associated with palsa upthrusting. Although thicker snowpack preventing deeper frost penetration into the soil is maintained by the development of a forest/krummholz cover, wooded palsas at the treeline can survive because of low annual temperatures, reduced solar radiation beneath the tree canopy, variable accumulation and duration of annual snowpack [Cyr, Payette, 2012].

Palsas in Usa River valley and in Northwest Siberia are of different age and represent all varieties of Seppala-type palsa stages such as embryo-mature-degraded ones. Palsa formation took place in different time periods both in different geocryologic zones and within separate palsa massifs. The transition from low-moor peat to that accumulated during a subaerial stage and, consequently, heaving of the palsas occurred in the periods lasting from 7.5 to $6.7 \mathrm{ka}$ BP and from 3.3 to $1.4 \mathrm{ka}$ BP. Later, this process stabilised, and palsas grew slowly. The slow heaving of the young palsas commenced 3.3-1.4 ka BP and still continues. In northern areas with continuous permafrost palsas are stable and can grow even in case of global climate warming. In discontinuous permafrost conditions most part of palsas can thaw very fast.

\section{CONCLUSIONS}

1. Convex peat mounds (palsa) are found in Northern Europe both in the areas of continuous permafrost and in the discontinuous and sporadic permafrost.

2. The southern limit of palsa in the NorthEast of Europe coincides with southern 
border of permafrost ground: in the Kola Peninsula it is about $67^{\circ} 50^{\prime} \mathrm{N}$, in the Kanin Peninsula about $67^{\circ} \mathrm{N}$, in the Nenets Autonomous District to the South of 67010 $\mathrm{N}$, in Bolshezemel'skaya Tundra to the South of $66^{\circ} 20^{\prime} \mathrm{N}$.

3. The palsa area in the North-East of the Europe located in the low-temperature continuous permafrost and it enters up to $68^{\circ} 10^{\prime} \mathrm{N}$ in the Nenets Autonomous District and to $67^{\circ} 30^{\prime}-68^{\circ} \mathrm{N}$ in Bolshezemel'skaya Tundra.

4. Palsas are not always degraded in the Holocene Optimum, even in the southern part of the permafrost area, but on the contrary, new palsas started to form. An intense accumulation of peat (due to high summer temperatures), and its good preservation (due to severe winters) in the Holocene Optimum are main factors of such geocryological paradox.

5. Some of the mounds develop cyclically: surface thermokarst processing of previously formed palsa leads to abrasion and subsidence part of them, and the subsequent draining ends with the formation of new palsa.

\section{ACKNOWLEDGMENTS}

This work was partially supported by the Russian Foundation for Basic Research (project no. 11-05-01141) and Russian Federal Program "Scientific and pedagogical personnel of innovative Russia on 2012-2013 (lot 2012-1.112-000-1008-018, contract 8339).

\section{REFERENCES}

1. Áhman, R. (1976) The structure and morphology of minerogenic palsas in Northern Norway. Biuletyn peryglacjalny, N 26, pp. 25-31.

2. Allard M., Rousseau L. (1999) The internal structure of a palsa and a peat plateau in the Riviere Boniface Region, Quebec: inferences on the formation of ice segregation mounds. Geograpie Physique et Quaternaire, vol. 53, N 3, pp. 373-387.

3. Barcan V.Sh. (2010). Stability of palsa at the southern margin of its distribution on the Kola Peninsula. Polar Science, vol. 4, Iss. 3, pp. 489-495.

4. Blyakharchuk T.A., Sulerzhitsky L.D. (1999). Holocene vegetation and climatic changes in the forest zone of Western Siberia according to pollen records from the extrazonal palsa bog Bugristoye. The Holocene, N 9, Iss. 5, pp. 621-628.

5. Christensen T.R, Jackowicz-Korczyński M, Aurela M, Crill P, Heliasz M, Mastepanov M, Friborg T. (2012). Monitoring the multi-year carbon balance of a subarctic palsa mire with micrometeorological techniques. Ambio, vol. 41, Iss. 3, pp. 207-217.

6. Cyr S., Payette S. (2010). The origin and structure of wooded permafrost mounds at the arctic treeline in eastern Canada. Plant Ecology \& Diversity, vol. 3, N 1. P.35-46.

7. Farbrot H., Isaksen K., Etzelmüller B., Gisnås K. (2013). Ground Thermal Regime and Permafrost Distribution under a Changing Climate in Northern Norway. Permafrost and Periglacial Processes, vol. 24, N1, pp. 20-38.

8. Lewkowicz A.G., Coultish T.L. (2004). Beaver Damming and Palsa Dynamics in a Subarctic Mountainous Environment, Wolf Creek, Yukon Territory, Canada. Arctic, Antarctic, and Alpine Research, vol. 36, N 2, pp. 208-218.

9. Magnan G., Lavoie M., Payette S. (2012). Impact of fire on long-term vegetation dynamics of ombrotrophic peatlands in northwestern Quebec, Canada. Quaternary Research, vol. 77, pp. 110-121. 
10. Maksimova L.N., Ospennikov E.N. (2012). Evolution of mire systems and permafrost of Bolshezemelskaya tundra in Holocene. Earth Cryosphere, vol. 16, N 3, pp. 53-61. (In Russian).

11. McLaughlin J., Webster K. (2013). Effects of a changing climate on peatlands in permafrost zones: a literature review and application to Ontario's Far North. Climate research report CCRR-34.

12. Oksanen P.O., Kuhry P, Alekseeva R.N., Kanev V.V. (1998). Permafrost dynamicsat the Rogovaya River peat plateau, Subarctic Russia In Permafrost. Seventh International Conference. Proceedings. Yellowknife, Canada. Collection Nordicana, N 55, pp. 847-854.

13. Pissart A. (1983). Pingos et palses: Un essai de synthese des connaissances actuelles. In Mesoformen des Reliefs im heutigen Periglazialraum. Bericht uber ein Symposium. H.Poser and E.Schunke (Ed.). Abhandlungen der Akademie der Wissenschaften in Gottingen. Mathematische - Phys. Klasse. Vandenhoeck and Ruprecht. 3 Folge, N 35, pp. 48-69.

14. Popov A.I. (1967). Cryogenic phenomena in the Eath Crust (cryolithology). Moscow Moscow University press. 304 p. (In Russian).

15. Romanenko F.A., Garankina E.V. (2012). Permafrost formation and structure at the south border of cryolithozone, the Kola Peninsula. Earth Cryosphere, vol. 16, N 3, pp. 72-80. (In Russian).

16. Salonen J.S., Seppa H., Valiranta M., Jones V.J., Self A., Heikkila M., Seija Kultti S., Yang H. (2011). The Holocene thermal maximum and late-Holocene cooling in the tundra of NE European Russia. Quaternary Research, vol. 75, Iss. 4, pp. 100-111.

17. Seppälä M. (1971). Evolution of eolian relief of the Kaamasjoki-Kiellajoki River basin in Finnish Lapland. Fennia, N 104, pp. 1-88.

18. Seppälä M. (1986). Origin of palsas. Geografiska Annaler. Ser.A. Physical geography, vol. 68A, N 3, pp. 141-147.

19. Seppälä M. (2011). Synthesis of studies of palsa formation underlining the importance of local environmental and physical characteristics. Quaternary Research, vol. 75, pp. 366-370.

20. Väliranta M., Kaakinen A., Kuhry P. (2003). Holocene climate and landscape evolution East of the Pechora Delta, East-European Russian Arctic. Quaternary Research, vol. 59, N 3, pp. 335-344.

21. Välliranta M., Kaakinen A., Kuhry P., Kultti S., Salonen J. S., Seppä H. (2010). Scattered lateglacial and early Holocene tree populations as dispersal nuclei for forest development in north-eastern European Russia. Journal of Biogeography, vol. 38, Iss. 5, pp. 922-932.

22. Vasil'chuk Yu.K. (1983). About formation specific of palsas in the north-west Siberia during Holocene. In A.I.Popov and V.T.Trofimov (Eds.). Natural conditions of Western Siberia. Moscow. Moscow University publ. pp. 88-103. (In Russian).

23. Vasil'chukYu.K., Vasil'chuk A.C. (1998). The ${ }^{14} \mathrm{C}$ Age of Palsas in Northern Eurasia. Radiocarbon, vol. 40, N 2, pp. 895-904.

24. Vasil'chuk Yu.K., Vasil'chuk A.C., Budantseva N.A., Chizhova Ju.N. (2008). Palsa of frozen peat mires. Prof. Yu.K.Vasil'chuk (Ed.) - Moscow. Moscow University Press. 571 pp. (In Russian).

25. Vasil'chuk Yu.K., Vasil'chuk A.C., Budantseva N.A., Chizhova Ju.N. (2011). Palsas in the northern European Russia: the southern and northern limits of the areal and the modern dynamic. Engineering Geology, N 2, pp. 56-72. (In Russian). 
26. Vasil'chuk Yu.K., Vasil'chuk A.C., Budantseva N.A., Chizhova Ju.N. (2012). Palsas in the north of Western Siberia: the southern and northern limits of the areal and the modern dynamics. Engineering Geology, N 3, pp. 62-78. (In Russian).

27. Washburn A.L. (1983). Palsas and continuous permafrost. In Permafrost. Fourth International Conference. Proceedings. Fairbanks, Alaska. National Academy Press, Washington, D.C., pp. 1372-1377.

28. Westin B., Zuidhoff F.S. (2001). Ground thermal conditions in a frost-crack polygon, a palsa and a mineral palsa (lithalsa) in the discontinuous permafrost zone, northern Sweden. Permafrost and Periglacial Processes, vol. 12, N 4, pp. 325-335.

29. Yevseev V.P. (1976). Regularities of migrational palsas distribution in the northeast of the European part of the USSR. and Northwest Siberia. In Popov A.I. (ed.). Problems of Cryolithology. Moscow. Moscow University Press., vol. 5, pp. 95-159.

30. Zuidhoff F.S., Kolstrup E. (2000). Changes in Palsa Distribution in Relation to Climate Change in Laivadalen, Northern Sweden, Especially 1960-1997. Permafrost and Periglacial Processes, vol. 11, N 1, pp. 55-69.

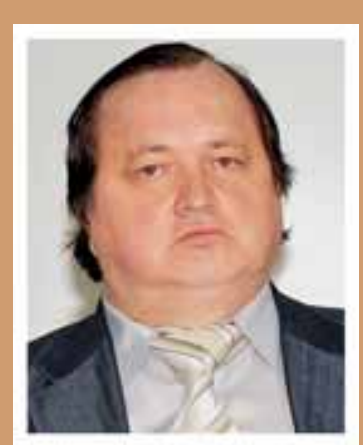

Yurij K. Vasilchuk is Professor of the Departhment of Landscape Geochemistry and Soil Geography of the Lomonosov Moscow State University. He obtained the PhD degree from the Moscow State University in 1982, under the supervision of Professor Trofimov, and the D.Sc. degree from the Permafrost Institute of RAS in 1991. He has held professor positions at the Cryolithology and Glaciology department of the Moscow State University in 1996, and was appointed to the position of full professor at the Departhment of Landscape Geochemistry and Soil Geography in 2009. His research interests have been concerned with the use of stable and radioactive isotopes in the massive ice and ice wedge, palsa and pingo, as well as in soils and landscapes. He was elected a member of the Russian Academy of Natural Sciences in 2004. He is the author of two university textbooks and 14 monographs.

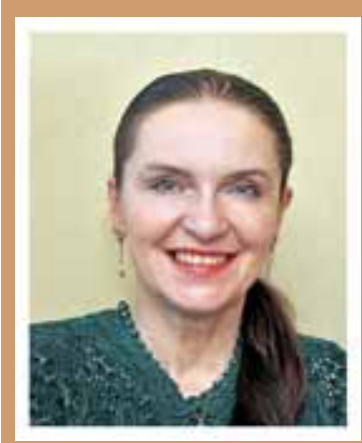

Alla C. Vasilchuk is Senior research Scientists of the Laboratory of Geoecology of the North of the Lomonosov Moscow State University. She obtained her PhD from the Moscow State University in 1987, under the supervision of Professor Lazukov and Dr.Vasil'chuk, and her Doctor of Science degree from the Geography Institute of RAS in 2009. In 2004 she joined the staff of the Moscow State University to begin work on "Pollen ratios in the massive ice and ice wedge and palsa". More recently, she has developed possibility to identify massive ice origin with confidence by pollen. She is the author of 4 research monographs, including "Palsa of frozen peat mires". 

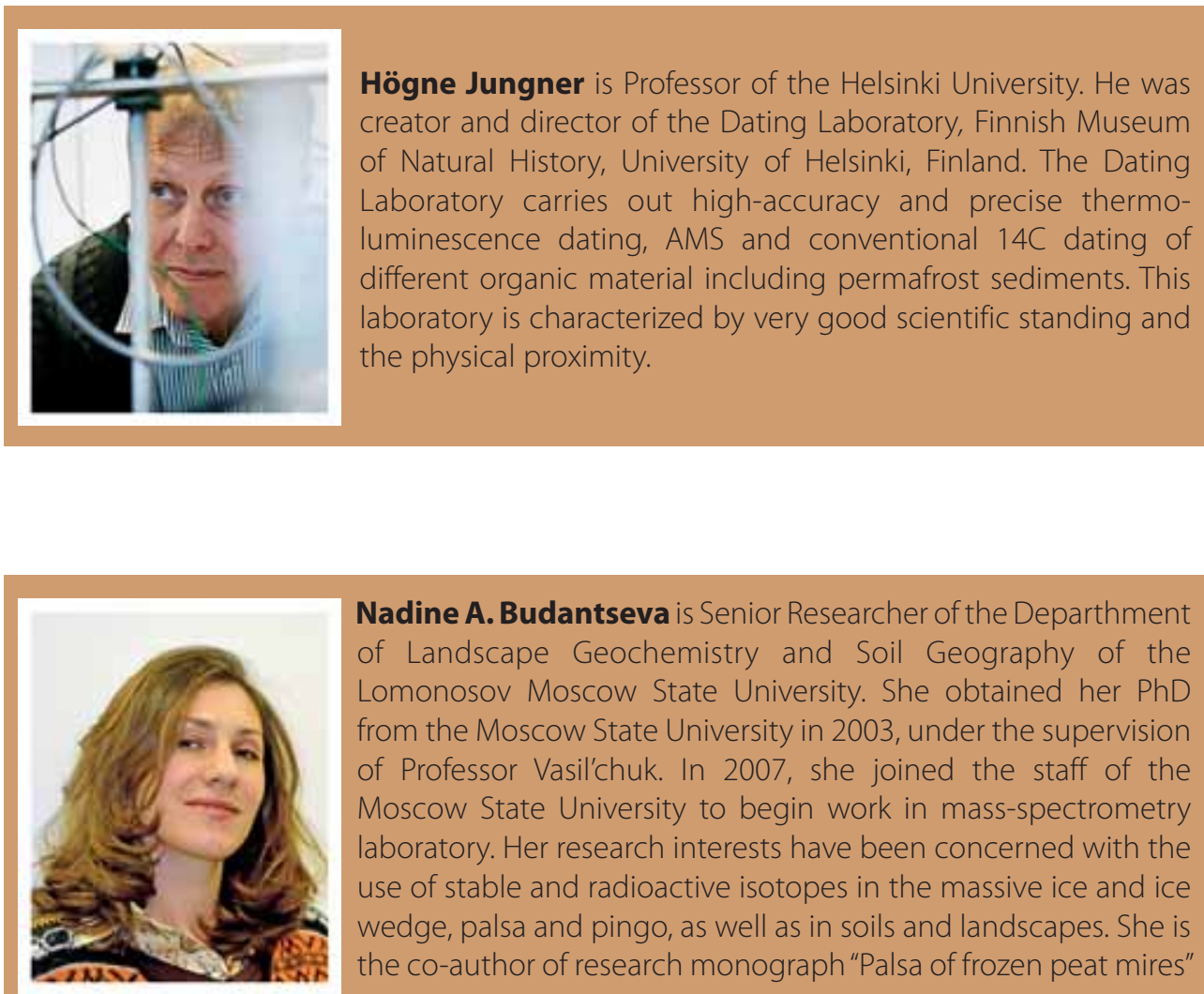

Nadine A. Budantseva is Senior Researcher of the Departhment of Landscape Geochemistry and Soil Geography of the Lomonosov Moscow State University. She obtained her PhD from the Moscow State University in 2003, under the supervision of Professor Vasil'chuk. In 2007, she joined the staff of the Moscow State University to begin work in mass-spectrometry laboratory. Her research interests have been concerned with the use of stable and radioactive isotopes in the massive ice and ice wedge, palsa and pingo, as well as in soils and landscapes. She is the co-author of research monograph "Palsa of frozen peat mires"

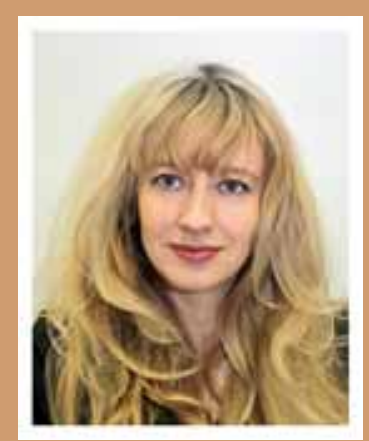

Julia N. Chizhova is Senior researcher of the Departhment of Landscape Geochemistry and Soil Geography of the Lomonosov Moscow State University. She obtained her PhD from the Moscow State University in 2006, under the supervision of Professor Vasil'chuk. In 2007, she joined the staff of the Moscow State University to begin work in mass-spectrometry laboratory on "Stable isotope ratios in the environment". Her research interests have been concerned with the use of stable and radioactive isotopes in the glaciers and palsa, as well as in soils and landscapes. She is the co-author of research monograph "Palsa of frozen peat mires". 